\title{
El falso testimonio judicial en el Derecho hispánico y anglo-sajón en el Medievo. Estudio comparado ${ }^{1}$
}

\author{
Luis Iglesias Rábade ${ }^{2}$
}

Recibido: 01 de julio de 2016 / Aceptado: 03 de febrero de 2017

Resumen. Este estudio compara las fuentes normativas hispánicas y anglo-sajonas relativas a la regulación del delito de falso testimonio en juicio en el período medieval. En el ámbito hispánico se hace referencia a los antecedentes del Derecho romano, haciendo hincapié en los elementos constitutivos del delito y en los títulos de punición del poder público instituido. Para el período medieval, se propone un método de estudio comparativo diacrónico en paralelo de las fuentes normativas hispánicas y anglosajonas. Para ello, el estudio discurre siguiendo una periodización en cuatro etapas históricas (Alta y Baja Edad Media temprana y tardía, respectivamente) estableciendo en cada una de estas fases los elementos comunes y distintivos de la regulación del delito.

El estudio analiza el objeto y los sujetos del delito de falsedad testimonial tanto en las fuentes normativas seculares como canónicas. Por ello, se examina el litigio jurisdiccional, especialmente en los territorios ingleses, entre el poder secular y eclesiástico para enjuiciar al perjuro y sancionarlo de acuerdo a la ley canónica o secular.

Se hace también una revisión respecto a cuál es realmente el interés jurídico protegido: la autoridad divina, la víctima o la correcta administración de justicia. En consecuencia, se examina la legitimación para perseguir el delito y la tipología de penas previstas las fuentes normativas seculares y canónicas para tutelar ese bien objeto de protección.

En el ámbito hispánico se recurre a la legislación visigoda en el Altomedievo y a los ordenamientos locales y territoriales en la Baja Edad Media, mientras que, en el contexto anglo-sajón, las carencias legislativas se suplen con los compendios del Common Law (especialmente el Britton y el Mirror of Justices), la doctrina jurídica de la época y la práctica forense que se registró en los Year Books respecto a este delito. Palabras clave: falso testimonio; derecho medieval; hispánico; anglo-sajón; estudio comparado.

\section{[en] False Legal Testimony in Hispanic and Anglo-Saxon Law in the Medie- val Period. A comparative Study}

\begin{abstract}
This study compares Hispanic and Anglo-Saxon regulatory sources governing the crime of giving false testimony during a trial in the medieval period. In the Hispanic sphere reference is made to precedents in Roman Law, emphasising which elements constituted a crime and the punishments applicable under the public authority in place at the time. For the medieval period, the paper puts forward a parallel diachronic comparative study method of Hispanic and Anglo-Saxon regulatory sources. To do this, the study follows a periodization of four stages in history (early and late High and Low Middle Ages respectively), setting out both the shared and particular elements of criminal law in place for regulating crime for each stage.
\end{abstract}

\footnotetext{
Me siento especialmente deudor, para el ámbito hispánico, de la obra de Alejandre, "El delito de falsedad testimonial en el Derecho histórico español".

2 Universidad de Santiago de Compostela luis.iglesias.rabade@usc.es
} 
The study analyses the object and subjects of the crime of false testimony both in secular and canonical law. The paper discusses jurisdictional litigation, especially in English territories, taking place between the secular and ecclesiastical power to bring the perjurer to trial and apply the punishment set out in canonical or secular law.

The discussion also looks at which legal interest was really being protected in these cases, whether divine authority, the victim or the correct administration of justice. This leads to an examination of the legal standing for pursuing the crime and the types of punishments set out in secular canonical law to watch over the protected asset.

In the Hispanic sphere, Visigoth legislation is used in the High Medieval period and local and territorial law codes in the Lower Middle Ages, whereas in the Anglo-Saxon context, the legislative gap was filled by the compendia of Common Law (especially Britton and the Mirror of Justices), legal doctrine of the time and forensic practice recorded in the Year Books in respect of this crime.

Keywords: False Testimony; Medieval Law; Hispanic; Anglo-Saxon; Comparative Study.

Sumario: I. Los títulos de punición en el derecho romano. II. Estudio comparado de las fuentes hispánicas y anglo-sajonas. 1. El período altomedieval temprano. 1.1. Los elementos constitutivos del "tipo" en los territorios hispano-visigodos. 1.1.1. Fuentes seculares. 1.1.2. Fuentes canónicas. 1.2. La justicia vindicativa del clan en los territorios anglo-sajones. 2. El período altomedieval tardío. 2.1. El período posvisgodo hispano. 2.1.1. Regulación sustativa y procesal del Derecho secular. 2.1.2. La remisión canónica al Liber Iudiciorum. 2.2. Juicio compurgatorio y cojuradores en el ámbito territorial anglo-sajón. 3. El período bajomedieval temprano. 3.1. La regulación en el Derecho hispánico. 3.1.1 La adaptación del Liber a los ordenamientos locales. 3.1.2. La configuración del delito en el Ius Commune. 3.2. La desaparición de la prueba testifical en el proceso judicial inglés. 4. El período bajomedieval tardío. 4.1. Configuración del "tipo" penal y régimen sancionador en los ordenamientos locales y territoriales hispánicos. 4.2. El perjurio de los miembros del jurado en los territorios ingleses. 5. Conclusión.

Cómo citar: Iglesias Rábade, L. (2017) El falso testimonio judicial en el Derecho hispánico y anglosajón en el Medievo. Estudio comparado, en En la España Medieval 40, 67-110.

Desde que el hombre se ha organizado en estructuras sociales ha utilizado legítimamente el testimonio de otros como medio de prueba para hacer valer su derecho o su exculpación. Sin embargo, en ninguna época se evitó la inclinación mendaz por faltar a la verdad por ruego, precio o malquerencia, pese a su reprobación penal y a su nota de infamia. Es cierto que este delito ha sido escasamente perseguido y mucho menos sancionado, de ahí que en todas las culturas se haya faltado a la verdad impunemente, aun existiendo suficientes instrumentos normativos y títulos de punición para reprimir esta conducta.

El acto de deposición de testimonio está sujeto a un cierto grado de subjetividad en los procesos de recuperación de los hechos acaecidos, lo que puede conducir a una percepción errada. La apreciación de los hechos por un observador casual se ve afectada por confusas realidades, -capacidad de concentración en lo percibido, tiempo de observación, circunstancias más o menos traumáticas en que se producen los acontecimientos, tiempo transcurrido entre los hechos y su transmisión ante autoridad pública o judicial, etc.- que pueden distorsionar instintivamente la verdad. Por otra parte, el mismo órgano juzgador se enfrenta a otros elementos inherentes al acto de representación o transmisión de lo percibido por el testigo que dificultan un juicio cierto sobre la veracidad de la declaración. La firmeza del testigo en la fijación de los hechos, la forma de evocarlos, el nivel de instrucción para adaptarse a una representación escénica, el potencial y desconocido interés en la causa, etc. pueden 
afectar a la apreciación de un testimonio como falso. Todo esto justifica de algún modo la dificultad de detectarlo y perseguirlo.

\section{Los títulos de punición en el derecho romano}

La configuración jurídico-penal del delito de falso testimonio en el Derecho romano se remonta a la ley arcaica de las XII Tablas ${ }^{3}$, aunque en el ámbito procesal no existe propiamente una regulación específica de la prueba testifical judicial en una ley, senadoconsulto o constitución imperial ${ }^{4}$ anterior al Código Teodosiano ${ }^{5}$. La escueta referencia al falso testimonio de esta ley decenviral no nos permite determinar con mayor precisión las notas definitorias y los elementos constitutivos del "tipo" penal. Es difícil discernir hasta qué punto y en qué circunstancias el poder público de la época arcaica intervenía en una cuestión que afectaba a la esfera privada, pues la misma ley decenviral amparaba la venganza privada reactiva y una de sus formas de expresión era la obvagulatio ${ }^{6}$. No faltan voces que estiman que el rigor penal de las XII Tablas (despeñamiento de la Roca Tarpeia) se aplicaba incluso a la conducta calumniosa extrajudicial, pues el embuste malicioso debió ser un ilícito punible en la Roma arcaica ${ }^{7}$, apreciación que tiene su correlato en la tradición bíblica: "aquel que extiende la mentira, no escapará" 0 "perecerá".

En la Roma clásica probablemente sólo se sancionaba el falso testimonio como un medio de consumación de otro delito ${ }^{10}$, siendo el poder divino el juez de la infamia. Los autores clásicos dejaron constancia de que el delito de falso testimonio atentaba a la autoridad divina, de la cual emanan los títulos de punición del perjurio. Advertía Tiberio que el poder de los hombres no puede inmiscuirse en las injurias divinas, de modo que correponde a los dioses ocuparse de ellas con la muerte del infractor. Cicerón también manifestó que la pena humana del perjurio es el deshonor, la divina es la muerte ${ }^{11}$, sanción a la que también alude Tito Livio ${ }^{12}$, pues la fides jurada del hombre

T. 8, 23: "qui falsum testimonium dixisse convictus esset, e saxo Tarpeio deiceretur" (en GELIO, Aulo, Noctes Atticae, 20, 1, 53).

4 El delito de falso testimonio adquirió carta de naturaleza con un tratamiento autónomo e independiente con el Senadoconsulto Liboniano (Alejandre, "El delito de falsedad testimonial", p. 22).

5 Fernández de Buján Fernández, Antonio, "Testigos y documentos", pp. 117-118. Es en el Bajo Imperio cuando el Código Teodosiano (XI, 39) bajo el título, De fide testium et instrumentorum, presenta una ordenación procesal de la prueba testifical haciéndola prevalecer a la prueba documental. Del mismo modo el Digesto refuerza el valor probatorio de la prueba escrita siempre y cuando el negocio jurídico que documenta esté avalado por el testimonio de testigos de "dignidad, veracidad, buenas costumbres y gravedad" (Dig. 22,3,5) o "fidedignos" por cuanto la persona que depone testimonio "es honorable" o porque "no lo da por lucro, favor o enemistad" (Dig. $22,3,5)$.

6 Era costumbre que el querellante y su familia se personasen ante la puerta de la casa del testigo que rehusaba a prestar testimonio requiriéndole a voz en grito -cada tres días- para que acudiese ante la autoridad judicial. Vid. Arias Bonet, "Prueba testifical y 'obvagulatio' en el antiguo Derecho romano", pp. 293-300. La obvagulatio irrogaba además una infamia facti (Mommsen, Römisches Strafrecht, p. 668). Vid. también Alejandre, "El delito de falsedad testimonial", p. 20.

7 Mommsen, Römisches Strafrecht, p. 668. No obstante, la severidad de la pena que se prescribe para el testigo falso en la Tabla VIII, 23 parece contradecir a Mommsen.

8 Proverbios, $19,5$.

$9 \quad$ Ibidem, 19,9.

10 Vid. Archi, Problemi in tema di falso, p. 58 y Alejandre, "El delito de falsedad testimonial", p. 23.

11 Cicerón, De Legibus, 2,9,22: "Periurii poena divina exitium, humana dedecus"

12 Liv. 39, 18, 4: "qui falsis testimoniis (signis adulterinis, subjectione testamentorum, fraudibus aliis) contaminati, eos capitali poena adficiebant". 
libre era la prueba más valiosa y respetada en el ámbito judicia ${ }^{13}$. Opinaba Cicerón que las letras -la prueba documental- no pueden prevalecer sobre el testimonio, el juramento y la credibilidad incorrupta de los hombres (ciudadanos libres) ${ }^{14}$.

El régimen jurídico de la falsedad testimonial se elabora en el Bajo Imperio, fruto de la labor interpretativa de la Ley Cornelia de falsis, por los jurisconsulto ${ }^{15}$ Paulo $^{16}$, Ulpiano $^{17}$, Modestino ${ }^{18}$ y Marciano ${ }^{19}$, quienes configuran no sólo la naturaleza jurídica del delito - que se asienta en la nota de falsedad ${ }^{20}$-, sino también los elementos del "tipo" básico: el testimonio falso (o la verdad silenciada ${ }^{21}$ ) depuesto libremente en causa judicial ${ }^{22}$ mediando dolo malo ${ }^{23}$ bien sea en beneficio propio o perjuicio ajeno. Más controvertida es la motivación del delito. Siguiendo la interpretación de Paulo, la Lex Cornelia de falsis sólo sancionaría el testimonio mendaz por precio o malquerencia ${ }^{24}$.

La "tipicidad" descrita probablemente se irrogaba independientemente de que el testimonio fuese acompañado de juramento (asertivo o promisorio ${ }^{25}$ ). Si bien es cierto que en la época de Quintiliano ya se reconocía que la veracidad de la palabra dada traía causa del juramento ${ }^{26}$, aunque la obligatoriedad del juramento no se recoge expresamente hasta el Codex Theodosianus en el s. V ${ }^{27}$. Por su parte, el Código de Justiniano, un siglo más tarde, prescribe la obligatoriedad del juramento in religione antes de deponer testimonio, determinando expresamente, además, que la credibi-

13 Vid. Fernández de Buján Fernández, Antonio, “Testigos y documentos”, pp. 117-142; Murga Giner, Derecho romano clásico, II: El proceso, p. 140; Costa, Crimine e pene da Romolo a Giustiniano, p. 27; Mommsen, Römisches Strafrecht, pp. 80-82.

14 Cicerón, Pro A. Licinio Archia Poeta Oratio, 4,8. Vid. también en el Derecho justineaneo, Nov. 73,3: “et aliud quidem faciebat collatio litterarum aliud vero testimonia, tunc nos quidem aestimavimus ea quae a viva dicuntur voce et eam iureiurando, haec digniora fide quam scripturam ipsam secundum se subsistere". Igual primacía se dispone en el Código Teodosiano XI, 39. En la época posclásica, cuando Constantino introduce el documento constitutivo o dispositivo, se establece que tanto vale la fe de los instrumentos quirográficos como las declaraciones de testigos [CJ. 4,21,20: "In exercendis litibus eandem vim obtinent, tam fldes instrumentorum, quam depositiones testium”)], así como que no debe prevalecer el testimonio no escrito sobre el testimonio escrito [(CJ. 4, 20, 1: "Contra scriptum testimonium non scriptum testimonium (non fertur)...proferetur" (cito por Fernández de Buján Fernández, Antonio, “Testigos y documentos”, p. 118 y notas 4 y 5).

15 Las sucesivas referencias a los jurisconsultos Paulo, Ulpiano, Modestino y Marciano y al Digesto se citan por Mommsen, Theodor y Krueger, Paul, Corpus Iuris Civilis.

16 Paulo, Sent. 5, 15,5; 5,25,2; 5,25,3; 5,25,9; 4,7,1; 4,7,5 y 4,7,9.

17 Ulpiano, Coll., 8,7,1.

18 Modestino, Dig. 48, 10, 33 y 48,10,27,1.

19 Marciano, Dig., 48,8,1,1.

20 Vid., Paulo, Sent. 5,25,3: "Falsum est quidquid in veritate non est, sed pro vero adseveratur"; Dig., 48,8,1,1 (Marc.): "qui(ve) falsum testimonium dolo malo dixerit”; Paulo, Sent., 5,15,5: "qui falso vel varie testimonia dixerunt"; ibidem, 5,23,1: "qui... falsum testimonium dixerit"; ibidem., 5,25,2: "Qui ob falsum testimonium perhibendum".

21 Silenciar la verdad era también elemento constitutivo del "tipo" cuando se producía una desfiguración de la verdad, vid. Alejandre, "El delito de falsedad testimonial", p. 23.

22 Paulo, Sent., 5,25,2: "Qui ob falsum testimonium perhibendum vel verum non perhibendum ... ut sententiam ferat vel non ferat".,"; Dig. 48,8,1,1 (Marc.): "qui(ve) falsum testimonium ... dixerit, quo quis publico iudicio rei capitalis damnaretur".

23 Dig. 48,8,1,1 (Marc.): "qui(ve) falsum testimonium dolo malo dixerit"

24 El juez no tendría por qué averiguar las motivaciones del delito, sino exclusivamente su consumación. Vid. Alejandre, "El delito de falsedad testimonial", pp. 25-26.

25 Arias Bonet, "Prueba testifical y ‘obvagulatio' en el antiguo Derecho romano”, p. 292.

26 Idem. Vid. también Alejandre, "El delito de falsedad testimonial", pp. 24-25 y Fernández Espinar, El falso testimonio, p. 53.

27 Codex Theodosianus, 11,14, texto que se reproduce en el Liber Iudiciorum, 2,4,2, "Antiqua": "quia testes sine sacramento testimonium perhibere non possunt" (Fuero Juzgo en latín y castellano. Vid. también Alejandre, "El delito de falsedad testimonial", p. 34. 
lidad a la fe jurada sólo se presumía de los honestiores, aunque no la consideraba incorruptible, por ello sigue la aforismo unus testis nullus testis ya establecido en el Codex Theodosianus ${ }^{28}$.

La aplicación del régimen sancionador de la Lex Cornelia de falsis en la época republicana se alivió para el ciudadano libre, dado que podía eludir la pena de muerte con el exilio voluntario y la pérdida de la ciudadanía -interdictio aquae et igni-exigiéndose además la publicatio bonnorum en el período republicano tardío ${ }^{29}$. En el Bajo Imperio, hacia el s. III d.C, según señala Paulo, los "tipos" penales recogidos en la Lex Cornelia de falsis se castigaban con la deportación a un domicilio coactivo, generalmente una isla, para el infractor honestior, mientras que el humilior sufría la pena ad metalla o crucifixión ${ }^{30}$, salvo que la conducta falsaria del esclavo fuese inducida y ordenada por sus dueños, en cuyo caso se les exoneraba de culpabilidad ${ }^{31}$. Se aplicaba también el mismo régimen punitivo al inductor o sobornador ${ }^{32}$.

\section{Estudio comparado de las fuentes hispánicas y anglo-sajonas}

\section{El período altomedieval temprano ${ }^{33}$}

\subsection{Los elementos constitutivos del "tipo" en los territorios hispano-visigodos}

\subsubsection{Fuentes seculares}

Sin entrar en aspectos doctrinales relativos al grado de romanización del Derecho en el período altomedieval temprano hispano-visigodo y, en particular, en el análisis jurídico-doctrinal concerniente al criterio de la personalidad o territorialidad en la aplicación del Derecho "nacional" visigodo ${ }^{34}$, parto de la opinión más arraigada de

${ }_{28}$ CTh. $11,39,3$ y $C J, 4,20,10$.

29 Modestino, Dig. 48,10,33.

30 Paulo, Sent., 4,7,1 y 5,25,9.

31 En relación especialmente a la aplicación de la Lex Cornelia al delito de falsedad documental. Vid. Paulo, Sent., 4,7,1; 4,7,5 y 4,7,9 o Ulpiano, Coll., 8,7,1. Dig. 48,10,31.

32 Paulo, Sent., 5,25,2: "Qui ob falsum testimonium perhibendum vel verum non perhibendum pecuniam acceperit dederit iudicemve, ut sententiam ferat vel non ferat, corruperit corrumpendumve curaverit, humiliores capite puniuntur, honestiores publicatis bonis cum ipso iudice in insulam deportantur".

33 Para una comparación más coherente de las fuentes normativas hispánicas y anglo-sajonas se diferencian cuatro subperíodos históricos en la Edad Media: el Altomedievo temprano (último cuarto del s. V hasta finales del s. VII e inicios del VIII en el contexto hispánico), el Alto Medievo tardío (siglos VIII-X), el Bajo Medievo temprano (desde el s. XI hasta el último cuarto del s. XIII) y el Bajomedievo tardío (desde el último cuarto del s. XIII hasta el último cuarto del s. XV).

34 Según el criterio de la personalidad en la aplicación del Derecho en los territorios hispánicos visigodos, el Edictum Theodorici, por ejemplo, habría regido entre los visigodos invasores, mientras que los súbditos hispanoromanos se habrían acogido al Codex Theodosianus y la Lex Romana Visigothorum. Siendo así, podría haber una regulación distinta del falso testimonio en un mismo territorio. Pues bien, comparando las prescripciones legales del Edictum Theodorici con las de Lex Romana Visigothorum relativas a la regulación del delito de falsedad testimonial y su régimen sancionador, detectamos que el Edictum Theodorici incluía una regulación del "tipo" básico de falso testimonio por el que se sancionaba con pena de exilio al convicto de una declaración falsa o manifestación contraria a la verdad (Ed. Theod., XLII: "Qui varium aut falsum testimonium dixerint, aut utrique parti prodiderint, in exilium dirigantur", (cito por Rhon, Gothard, Commentatio ad Edictum Theodorici), y un "tipo" agravado para el falso testimonio mendaz depuesto por soborno con el objeto de obtener una sentencia contra iustitiam, prescribiéndose para el el sobornador y testigo pena de muerte, si los transgresores fueren humiliores, y confiscación de bienes si fuesen honestiores (Ed. Theod., XCI: "Qui testibus pecuniam dederit, ut falsum testimonium dicant vel certe quod sciunt taceant, aut non exprimant veritatem, vel iudici praemium 
que la Lex Romana Visigothorum fue el instrumento legislativo básico de los godos en los territorios hispánicos ${ }^{35}$. Pues bien, en lo que se refiere a la regulación de este delito, la Lex Romana Visigothorum se limita a reproducir los elementos distintivos del "tipo" penal descritos por Paulo al que aplica el mismo régimen sancionador talional para el falsario que provocase con su testimonio la condena a muerte de la víctima $^{36}$.

En cambio, el Liber a partir de Chindasvinto presenta una más extensa regulación del delito de falso testimonio judicial con nuevos elementos constitutivos del "tipo" básico y el "tipo" agravado para el inductor y el testigo cómplice, así como una enumeración de las personas inhábiles para deponer testimonio ${ }^{37}$. El régimen punitivo se suaviza con relación al previsto en la Lex Romana Visigothorum. Así, si el infractor era maior persona sería castigado con la confiscación de su patrimonio por un valor equivalente al daño causado, además de inhabilitarle a perpetuidad para comparecer en juicio como testigo ${ }^{38}$; mientras que la minor persona falsaria -a la que no se le presumía capacidad patrimonial para resarcir su delito- se le degradaba a la condición de siervo de la víctima del falso testimonio ${ }^{39}$.

dederint, ut sententiam contra iustitiam dicat, vel non iudicet, humiliores capite puniantur, honestiores bonorum suorum amissione multentur"(cito por ibidem). En defensa de la personalidad en la aplicación del Derecho en los territorios hispánicos visigodos, vid. Collins, Roger, "Visigothic law and regional custom", pp. 85-104; del mismo autor, "Law and Ethnic Identity", pp. 1-28; Lear, "The Public Law of the Visigothic Code", pp. 1-24; King, Law and Society in the Visigothic Kingdom; también del mismo autor "The alleged Territoriality of Visigothic Law", pp. 1 y ss. Schultze, "Mit einem Exkurs Zur Geschichte der westgotischen Rechtsquellen", pp. 105-130; Sánchez Albornoz, "Pervivencia y crisis de la tradición jurídica romana en la España goda", pp. 1009-1065.

35 La publicación de García-Gallo, "Nacionalidad y territorialidad del Derecho en la época visigoda", pp. 168-264, desarrolló la teoría de la territorialidad en la aplicación del Derecho godo, a la que se unieron renombrados juristas como Pérez-Prendes Muñoz-Arraco, José Manuel, quien aporta una valiosa exégesis de la obra de García Gallo respecto a esta cuestión, aun cuando en su opinión la teoría de la territorialidad admite alguna matización, como se desprende de este aserto: "El pueblo visigodo constituyó una comunidad transterrada completa y vertebrada como tal, no una serie de personas aisladas en trance de emigración. Además, sus monarcas asumieron el poder político sobre el conjunto resultante de su propio pueblo y la población sumamente mayoritaria, preexistente en el territorio hispánico donde aquel se asentaba. Así las cosas, cabe añadir que el papel jugado por el Derecho tuvo que ajustarse inevitablemente a esos presupuestos", por ello el 'Código de Eurico' hubo necesariamente de nacer para jugar un papel importante como guía normativa del grupo gótico especialmente en su relación con el mundo romano, completando de ese modo la semiesfera jurídica de los negocios solucionables apelando al soporte del Derecho consuetudinario. Quizá la expresión "nacionalidad-personalidad" de las leyes resulte poco comprensiva de esa realidad de ambos hemisferios" ("La Piedra Ensimismada", p. 83); respecto a la teoría de la territorialidad vid. también López-Amo, Ángel, "La polémica en torno a la territorialidad del Derecho visigodo", pp. 227-241 y D’Ors, "La territorialidad del Derecho de los visigodos", pp. 91-124. Para una revisión de la posición personalista y territorial en la aplicación del Derecho godo, y las matizaciones y revisiones de los autores citados respecto a su posición original de la territorialidad del Derecho, vid. Alvarado Planas, El problema del germanismo en el Derecho español. Siglos V-XI, para el “estado de la cuestión”, cap. I, pp. 15 y ss.

36 Lex Rom. Visig., 5, 25,1: "falsum testimonium dixerit, quo quis periret, mortisve causam praestiterit. Quae omnia facinora in honestiores poena capitis vindicari placuit: humiliores vero in crucem tolluntur aut bestiis subiciuntur" (cito por Girard, Paul F. y Senn, Félix, Textes de droit romain). Vid. supra, Paulo, Sent., 5,23,1.

37 Lib., 2,4,1 (Chindasvinto): De personis, quibus testificari non licet: Homicidae, malefici, fures, criminosi, sive venefici, et qui raptum fecerint, vel falsum testimonium dixerint, seu qui ad sortilegos, divinosque concurrerint, nullatenus erunt ad testimonium admittendi" (cito por Fuero Juzgo en latín y castellano).

38 Lib., 2,4,6 (Chindasvinto): "si maioris loci persona est, det ille de propia facultate sua, contra quem falsum testimonium dixerat, tantum quantum per testimonium eius perdere debuit, et testificare ultra non noverit" (cito por ibidem).

39 Lib., 2,4,6 (Chindasvinto): "Quod si minoris loci persona est, et non habuerit unde componat, ipse tradatur in potestatem illi, contra quem falsum testimonium dixerat, serviturus» (cito por ibidem). Así plateado el reproche penal del Liber (Chindasvinto), se detectan ciertas inconsistencias a efectos del régimen sancionador, puesto que no se determina el alcance talional o compensatorio de la sanción. Entendemos que el juez, a su albedrío, castigaría con pena arbitraria a la maior persona -que no dispusiese de suficiente patrimonio para resarcir el daño ocasionado- y a la minor persona, cuyo delito no tuviese entidad suficiente para obligarle a la condición servil de la víctima a perpetuidad. 
El Liber no incorpora el "tipo" agravado en términos similares al descrito, por ejemplo, en el Edictum Theodorici de los ostrogodos ${ }^{40}$. En este texto se dispone que el testigo venal y mendaz, que recibe prebenda o dádiva para deponer falsamente en juicio, sufra mayor castigo. El Liber se limita a disponer que el inductor que, "por ruego o por engaño", persuadiese a testigo para que prestare falso testimonio, recibirá junto con el deponente cómplice, la pena de falsos ${ }^{41}$, cuya determinación no se especifica, pero ajustándose a otras previsiones del Liber y de las copias interpoladas del mismo que circularon, habrían de ser castigados con pena corporal de cien azotes y correctivo perpetuo infamante de decalvación ${ }^{42}$. Hemos de coincidir con Alejandre que en la práctica judicial bajo la denominación del sujeto activo "inductor" el juez habría incluido al sobornador ${ }^{43}$, de ahí que se contemple para él una responsabilidad agravada.

Antes de Ervigio, el Liber no resuelve adecuadamente si el "tipo" sólo se configura cuando la declaración es contraria al reo o a una de las partes. Cuando se determina que "Si quis contra hominem...falsum dicere testimonium ${ }^{44}$ o Si quis autem contra eos habuerit testimonium dicere" 45 , se podría interpretar que no se penalizaría ni la verdad silenciada ni el falso testimonio a favor del reo o de las partes; sin embargo, a partir de Ervigio se prevé expresamente el castigo de toda declaración falsa ${ }^{46}$.

El Liber exige el juramento del testigo para deponer testimonio ${ }^{47}$, dictando, además, que si lo rehusaba sería inhabilitado a perpetuidad para testificar-si era maior persona-, imponiendo, además, el castigo de cien azotes y marca infamante de decalvación, si era minor persona ${ }^{48}$. Pese a que persisten todavía dudas respecto a si el juramento era anterior o posterior a la deposición de testimonio en la época visigoda ${ }^{49}$, lo cierto es que, atendiendo a la legislación procesal del Liber, el juramento parece que se prestaba después de haber depuesto testimonio siguiendo la práctica procesal de los pueblos germánicos ${ }^{50}$.

El falso testimonio atentaba a la esfera privada, de suerte que el procedimiento se promovía a instancia de parte. Siendo así, el Liber prevé unos plazos para que la víccopulare periurii” (cito por Fuero Juzgo en latín y castellano). Vid. Fernández Espinar, El falso testimonio, pp. 48-49.

47 No obstante, Petit corrobora el carácter marginal o secundario del uso expiatorio del juramento de parte, al menos tras la legislación de Eurico (Petit, Iustitia Gothica, pp. 298-301.

48 Lib., 2,4,2: "Certe si admonitus quisquam a iudice de re, quam novit, testimonium perhibere noluerit, aut si nescire se dixerit, id ipsum etiam iurare distulerit, et per gratiam, aut per venalitatem vera suppesserit; si nobilis fuerit, testimonium postea in nullo iudicio dicere permittatur, nec testimonium ipsius recipiatur ulterius. Quod si, licet ingenuae, minoris tamen fuerint dignitatis personae, et testimonio careant, et centum flagella infamati suscipiant" (cito por Fuero Juzgo en latín y castellano). Para un estudio más detallado de las penas en el Liber, incluida la de inhabilitación del testigo falso, vid. Orlandis, "Las consecuencias del delito en el Derecho de la Alta Edad Media", p. 63 y ss.

49 Vid. Brunner, ( $8^{\mathrm{a}}$ ed. de von Schwerin, Claudius), Historia del Derecho germánico, pp. 26 y ss. y también Merea, "Da miña gaveta", pp. 171 y ss. Vid. Alejandre, "El delito de falsedad testimonial", p. 34.

50 Lib., 2,4,2: "Iudex, causa finita, et sacramento secundum leges, sicuti ipse ordinaverit, a testibus dato, iudicium emittat". La versión vulgarizada del Liber, el Fuero Juzgo $(2,4,2)$ es igualmente clarificadora: "El iuez, pues que el pleyto fuere acabado, é las testimonias fueren recabdadas ó iuradas, assi cuemo es derecho, deve dar el iuyzio entre las partes" (cito por Fuero Juzgo en latín y castellano).
} 
tima pueda iniciar el proceso $^{51}$, no obstante, expresiones como (falsum testimonium) potestas iudiciara comprobat ${ }^{52}$ vendrían a confirmar una potencial persecución de oficio $^{53}$. Esto nos lleva a pensar que este "tipo" delictivo atentaba no sólo a la víctima y a Dios - por jurar falsedad en su nombre ${ }^{54}-$, sino también a la garantía procesal y a la fé pública, que es el interés objeto de protección.

\subsubsection{Fuentes canónicas}

La legislación conciliar canónica hispánica del Altomedievo temprano sancionaba con la excomunión al testigo falso. Ya el Canon 74 del Concilium Eliberritanum, en la primera década del s. IV, prescribía que el Falsus testis, prout est crimen, absti$n e b i t u r^{55}$. Este Canon recogía una prescripción de carácter general que dictaba que todo testigo falso sería sancionado con la pena de excomunión y ésta se aplicaría por el juez eclesiástico atendiendo al tipo de delito que el falsario hubiere imputado a otro $^{56}$. Este mandamiento genérico de los Padres de la Iglesia sólo venía a reafirmar el carácter delictivo del falso testimonio, siguiendo los postulados bíblicos a los que ya se ha hecho referencia, y la forma de sanción que debía recibir el transgresor (la excomunión). Serían, pues los jueces eclesiásticos los que determinarían el tiempo de la pena atendiendo a las múltiples formas y circunstancias en que se podría incurrir en falso testimonio ${ }^{57}$.

Lib., (Ervigio) 2,4,7; Lib., (Egica) 2,7,8.

Lib., (Chindasvinto) $2,4,7$.

53 Petit señala que, en el proceso visigodo establecido en Liber, el "contrapunto" al régimen acusatorio lo constituía la "iniciativa de oficio (inquisitio)" para la persecución de algunos delitos (Petit, Iustitia Gothica, pp. 187 y 194 202). Vid. también Fernández Espinar, El falso testimonio, p. 65.

54 San Isidoro recogiendo casi el mismo texto de San Agustín (Decretales, 5,20) decía: "Testis falsidicus tribus est personis obnoxius. Primum Deo, quem periurando contemnit; sequenter iudici, quem mentiendo fallit; postremo inocenti quem falso testimonio laedit" (San Isidoro, Sententiarum, 3,55,2 (cito por Documenta Catholica Omnia). El falso testimonio se considera una ofensa a Dios en el Deut., 19,16,21: "Si stiterit testis mendax contra hominem accusans eum prevaricationis, stabunt ambo quorum causa est ante Dominum in conspectu sacerdotum et iudicum. Cunque diligentissime perscrutantes, inveniunt falsum testem dixisse mendacium contra fratrem suum, reddent ei sicut fratri suo facere cogitavit, aut audientes ceteri metum habeant, et nequaquam audeant facere" (cito por Scio de San Miguel, Felipe, La Biblia Vulgata Latina); en el Libro de los Salmos, 62. En la tradición bíblica, el testigo falso o el que acusa falsamente bajo juramento (Lev. 5:1; 6:2 ff; Prov. 29:24), o aquél que incumple una promesa jurada (1 Sam. 19:6; 20:17; 2 Sam. 15:21; 19:23) invoca la ira divina y una maldición cae sobre sí mismo (Mt. 26:74), independientemente del tipo de negocio jurídico o relación mercantil en que dicha falsedad se deponga: en asuntos de Estado (Ant., XV, x, 4), en actividad comercial (Gen. 24:37; 50:5; Ez. 10:5), en sede judicial (Ex 22:11; Lev 6:3,5). Nuestra tradición bíblica abunda en referencias a la promesa dada bajo juramento y su invocación a la divinidad: "Y mi amo me hizo jurar, diciendo: No tomarás para mi hijo mujer de las hijas de los cananeos" (Gen. 24:37); "Entonces serás libre de mi juramento" (Gen. 24:41); o los padres a sus hijos: "Mi padre me hizo jurar" (Gen. 50:5). "Y Faraón dijo: Ve, y sepulta a tu padre, como él te hizo jurar" (Gen. 50:6); o el líder a su pueblo representado en sus dirigentes: "Entonces se levantó Esdras, pidió a los príncipes de los sacerdotes y de los Levitas que jurasen, y a todo Israel, que harían conforme a esto; y ellos juraron". (Esd., 10.5). Las transacciones comerciales se realizaban en presencia de testigos en la puerta de la ciudad (Gen. 23; Ruth, 4); los contratos se avalaban con testigos (Jer. 32, 12); el testigo de un delito era el primer en arrojar la primera piedra contra el transgresor (Deut. 13, 17); el falso testimonio en sede judicial (Ex. 20, 14; 23, 1; Deut. 5, 17. La autoridad eclesiástica mantuvo una preocupación constante por la punición de este delito, vid. las Constituciones Apostólicas, 7, 1, 4: "Non peierabis: dictum est enim ne iures omnino; quod si non faceris, saltem iustum iusiurandum iures, quoniam Laudabitur omnis, qui iurat in idpsum. Falsum testimonium non dices, quoniam qui criminatur pauperem, irritat eum, qui illum creauit" (cito por Romano, Clemente, De Constitutionibus Apostolicis, Venecia, 1563).

55 Concilium Illiberritanum, Cánon 74. Cito por Labbé y Cossart, Sacrosancta concilia, vol. I. p. 978.

56 Vid., con más detalle, Hera Pérez-Cuesta de la, "'Falsus testis' y 'Delator'”, pp. 377 y ss.

57 Ibidem, p. 377. 
Continuaba el referido Canon con otras tres prescripciones: Si tamen non fuerit mortale, quod objecit, et exprobaverit; quod non tacuerit, biennii tempore abstinebitur: si autem non probaverit conventui clericorum, placuit per quinquennium absti$n e i^{i 5}$. De donde se deduce, en primer lugar, que si la imputación falsaria provocaba la pena de muerte de la víctima objeto de falso testimonio, el testigo sería sancionado con la pena de excomunión perpetua, pues su falsedad era equiparable al delito de homicidio. La redacción de las otras dos prescripciones del canon han sido objeto de múltiples interpretaciones. Alberto de la Hera las ha recogido con gran detalle y dejó constancia de su propia acotación con copiosa y extensa argumentación ${ }^{59}$. Recogemos la interpretación de este autor: si el falsus testis pudiera probar la veracidad de su testimonio, esto es, la adecuación de su testimonio a la realidad, no podría imputársele falsedad y, en consecuencia, tampoco sería merecedor del castigo de dos años de excomunión. Por ello, propone "repensar el valor" que los Padres quisieron dar a las palabras "falsus testis", que bien podría ser el de aquél que no "testifica de un hecho falso, sino quien testifica falsamente...de un hecho que no conoce" 60 .

A mi modo de ver la interpretación sería más sencilla, atendiendo al significado de exprobo, la prescripción conciliar mencionada podría expresarse del siguiente modo: si el testigo explicaba los motivos que le habían impulsado a testificar falsamente (imputar una falsedad a otro) o los motivos por los cuales no habría podido callarse (coacción, miedo insuperable, etc.), se le castigaría a dos años de excomunión, pues habría existido deposición falsa ante el juez o consejo eclesiástico. En cambio, si el testigo no pudiese explicar satisfactoriamente los motivos que le habrían impulsado a declarar falsamente, se le castigaría a cinco años de excomunión. Pues en este último caso, se presumiría que habría actuado por malquerencia, dádiva o soborno.

En este sentido coincido con Alejandre cuando, según creo, afirma que el canon 74 del Concilio de Elvira presupone el deber procesal de que la autoridad judicial tenga que probar la verdad. Ciertamente, el juez eclesiástico debe requerir al testigo a que pruebe los motivos por los que faltó a la verdad. Empero, para que el juez eclesiástico le dé esa oportunidad al testigo, tuvo que probar previamente que éste faltó a la verdad.

Dado el carácter universal del Derecho eclesiástico, conviene hacer referencia a otros concilios que también dictaron normas relativas a la regulación de este delito. Por ejemplo, el primer Concilio de Arlés del año 314 recoge también el castigo de la excomunión para los testigos falsos ${ }^{61}$. Pese a que de la literalidad del texto parece deducirse que dicha sanción es a perpetuidad, es posible que, al menos en la práctica judicial, el juez eclesiástico habría atemperado este rigor sancionador según las circunstancias del caso. Nótese que en el segundo Concilio de Arlés, se dicta expresamente que el obispo podrá armonizar la pena atendiendo al arrepentimiento del infractor $^{62}$, probablemente para adaptar la norma a la práctica forense eclesiástica.

Concilium Illiberritanum, Cánon 74. Cito por Labbé y Cossart, Sacrosancta concilia, vol. I. p. 978.

Hera Pérez-Cuesta de la, "Falsus testis'y 'Delator"”, pp. 378 y ss.

Ibidem, p. 388.

${ }_{61}$ Concilium Arelatense I. can. 14: "De his qui falso accusant fratres suos, placuit eos usque ad exitum non communicare”. Cito por Labbé y Cossart, Sacrosancta concilia, vol. I, p. 1428.

${ }_{62}$ Concilium Arelatense II. can. 24: "Eos qui falso-a fratribus suis capitalia objecisse convicti fuerint, placuit, usque ad exitum non comunicare (sicut magna synodus ante constituit), nisi digna satisfactione poenituerint". Cito por Labbé y Cossart, Sacrosancta concilia, vol. IV, p. 1013. 
También el cuarto concilio de Cartagena de 1436 dispone que los hombres de iglesia que hubiesen incurrido en falso testimonio se les castigará a la pena de excomunión, aunque el obispo puede admitirlo de nuevo a la comunión, si enmienda su error (por arrepentimiento), aunque quedaría excluido del cuerpo del clero a perpetuidad $^{63}$. En parecidos términos se reguló el delito de falsedad testimonial en el concilio de Vannes de 465, aunque en este caso sorprende la equiparación del falso testigo con el homicida ${ }^{64}$, lo que vendría a justificar el reproche penal. El mismo texto del canon del concilio de Vannes referido al testigo falso se reproduce también en el concilio de Agde del año $506^{65}$.

En conclusión, esta legislación conciliar relativa al falso testimonio expresamente dispone que el falso testimonio es un delito que se castiga con la excomunión y la exclusión del clero como prescripción de carácter general. En cada caso, será la autoridad eclesiástica la que determine, a su arbitrio, el tiempo por el que se dicta dicha sanción. Se abre paso así al arbitrio judicial, que como se observará, tuvo una clara influencia en el Derecho secular tras la recepción del ius commune.

\subsection{La justicia vindicativa del clan en los territorios anglo-sajones}

Desconocemos prácticamente el relato histórico de las tribus anglo-sajonas entre los siglos V-VII porque no se conservaron textos jurídicos o literarios escritos en su alfabeto rúnico, del que sólo se conservan algunas inscripciones. Sabemos que cuando llegaron a Inglaterra despojaron de su oficio a los magistrados romanos y que aplicaron su propio derecho consuetudinario transmitido oralmente, al margen de la tradición romana ${ }^{66}$. En realidad, hasta comienzos del s. VII -coincidiendo con el proceso de cristianización y el desplazamiento del alfabeto rúnico por el latino-no se inicia la actividad de codificación y recopilación escrita del derecho regio. Eso sí, cuando se compila se adapta, tanto en el ámbito penal sustantivo como procesal, al nuevo credo cristiano ${ }^{67}$. Los primeros Códigos de los monarcas anglo-sajones del Alto Medievo temprano no recogen expresamente el delito de falsedad testimonial o de otro tipo de falsedades, salvo la prescripción relativa a la adulteración del sello regio, que no se contemplaba como un crimen falsi, sino como un acto de traición

63 Concilium Carthaginense, IV, can. 55:'Ut episcopi accusatores fratrum excommunicent, et si emendaverint vicium, recipiat eos ad communionen non ad clerum". Cito por Collectio canonum Ecclesiae Hispaniae ex probatissimis ac pervetustis codicibus, p. 148.

64 Concilium Veneticum, can. 1: "censuimus homicidas et falsos testes a communione ecclesiastica submouendos, nisi paenitentiae satisfactione crimina admissa diluerint”. Cito por Munier, Concilia Galliae, vol. I, p. 151.

65 Concilium Agatense, Canon 37: "Censuimus homicidas et falsos testes a communione ecclesiastica submovendos, nisi poenitentiae satisfactione crimina admissa diluerint". (Cito por Labbé y Cossart, Sacrosancta concilia, vol. IV, p. 1389.

${ }^{66}$ Según Tucker, "Germanic tribesmen did not have a Roman sensibility of law...in such a family-based society, the laws of the folk-moot would probably have left much unsaid since the majority of legal disputes would have been settled internally" (Tucker, "Anglo-Saxon Law", p. 135). Sin embargo, muchos autores consideran que la legislación romana pervivió en alguna de sus manifestaciones tanto en la forma como en la función, vid. Wallace-Hadrill, Early Germanic Kingship; Harries y Wood (eds.), The Theodosian Code; Harries, Law and Empire in Late Antiquity; Matthews, Laying Down the Law, 2000; Jones, "The Legacy of Roman Law in PostRoman Britain", pp. 45-57.

${ }_{67}$ Como señala Holdsworth, "We expect therefore to find that the church exercised some influence over AngloSaxon law; and more so because, during this period, the close unity between church and state prevented the growth of a separate system of ecclesiastical courts...ecclesiastical canons and secular laws are hardly distinct" (Holdsworth, A History, vol. II, p. 22). 
al rey ${ }^{68}$. Teniendo en cuenta que el documento privado no representaba todavía un instrumento probatorio o de garantía de derecho, y por tanto, no se incorporaba a los autos en sede judicial, hemos de entender que los derechos y privilegios, los acuerdos entre particulares o clanes, las deudas contraídas, etc. se acreditarían en juicio por medio de testigos de parte (oath-helpers). Además, en el Alto Medievo temprano las concesiones reales de feudos y derechos se realizaban en régimen de posesión folkland, sin la emisión de un documento escrito ${ }^{69}$, de modo que el disfrute $\mathrm{o}$, en su caso, su entorpecimiento, se dirimía en sede judicial aportando prueba testifical. Lo único que podemos aventurar es que en este período Altomedieval temprano anterior al proceso de cristianización, los testigos falsos habrían sido sancionados por el clan con la pena de outlawry (destierro del clan, confiscación de bienes y membrum et vita a merced de cualquier miembro de la tribu) o mediante la venganza reactiva de la víctima y familiares (blood-feud).

\section{El período altomedieval tardío}

\subsection{El período posvisgodo hispano}

\subsubsection{Regulación sustativa y procesal del Derecho secular}

En los territorios reconquistados y en las comunidades mozárabes el Liber pervive con desigual impacto en la tradición oral ${ }^{70}$. Lo cierto es que tras la invasión musulmana, el Liber perdió capacidad de renovación y actualización, de modo que los primeros fueros locales, como el de León, readaptan el Liber a su época restableciendo algunas de sus disposiciones, creando o suprimiendo otras o simplemente modificándolas como, por ejemplo, el régimen sancionador del delito de falsedad testimonial ${ }^{71}$.

Si escasa es la regulación sustantiva de este delito en los "siglos mudos", más incertidumbre se cierne sobre su regulación procesal. Por eso, no podemos determinar con certeza qué tipo de juicio -compurgatorio, duelo judicial o juicio de ordalía-se podría entablar contra el testigo falso. Es posible que el inculpado podría haberse acogido a cualquiera de ellos dependiendo de su estatus social. Así, hasta el último cuarto del s. XIII ${ }^{72}$, la querella de falso testimonio entre caballeros se resolvía por el riepto $^{73}$, mientras que los otros estamentos sociales optarían por el juramento de su

68 Vid. Ethelred, v. 30.

${ }_{69}$ Como señala Stenton, "the stages by which these rewards to faithful companions passed into hereditary properties are unrecorded " (Stenton, Latin Charters of the Anglo-Saxon Period, pp. 60-61).

70 La aplicación del Liber en la Alta Edad Media no ha de entenderse como una aplicación directa de la ley escrita, sino como referente jurídico que se trasmite de generación en generación de forma oral y que adquiere carácter de derecho general supletorio u orientador de un "nuevo derecho, surgido de las necesidades del momento y, en consecuencia, con unas características comunes para todo el territorio dominado por cristianos" (Iglesia Ferreirós, "Derecho municipal, derecho señorial, derecho regio", pp. 125-126). Vid. Alejandre, "El delito de falsedad testimonial", p. 42.

71 Así, la sanción prevista en la disposición 2,4,6 del Liber relativa a la falsedad testimonial se adapta a la realidad social de la época y al régimen sancionador del Derecho territorial, de modo que la disposición 20 del Fuero de León ya no distingue a efectos de reproche penal la condición social del reo-maior o minor persona- ni se admite la degradación a la condición de siervo de la víctima prevista en el Liber.

72 Los representantes del Consejo solicitan al Rey Sancho IV que no obligue al testigo a probar su inocencia en batalla. Vid. Fernández Espinar, El falso testimonio, pág 74.

73 Otero Varela, "El riepto de los fueros municipales", pp. 153-173. 
inocencia - probándola con el testimonio de otros testigos o cojuradores-, o bien por el juicio de ordalía cuando el querellado no podía defenderse con testigos ${ }^{74}$.

\subsubsection{La remisión canónica al Liber Iudiciorum}

En el Altomedievo tardío, la Iglesia, a pesar de ser parte en muchos procesos y litigios sobre propiedad, no fue capaz de establecer una legislación uniforme en los territorios hispánicos, de modo que al igual que en el Derecho secular, se acudió a la costumbre, a los textos conciliares y al Liber Iudiciorum, lo que explica que la regulación del falso testimonio en el ámbito canónico presente divergencias notables, dependiendo del territorio, por la diversidad de fuentes ${ }^{75}$. Para uniformar la regulación del falso testimonio, en una época en que la prueba testifical había adquirido un relevante protagonismo en el procedimiento penal, la autoridad eclesiástica dispuso, en el Concilio de Coyanza de 1055, que se aplicase las disposiciones del Liber Iudiciorum para la regulación del delito de falsedad testimonial ${ }^{76}$. De modo que el carácter subsidiario que el Liber estaba adquiriendo respecto a los fueros locales, se convierte en ley general en cuanto a la regulación de este delito en el ámbito eclesiástico, lo que viene a configurar esta conducta como un instituto secular ${ }^{77}$. Esta remisión al Derecho secular para determinar los elementos constitutivos del "tipo" penal del delito de falsedad testimonial cometido por un hombre de iglesia, junto a las penas de carácter talional y corporal asociadas al delito, rompe con toda la tradición canónica y no tiene probablemente reflejo en otros territorios de la cristiandad.

No obstante, a mediados del siglo siguiente, en el Decreto de Graciano, se recuperan las prescripciones del Derecho justinianeo relativas al falso testimonio de eclesiásticos, dejando sin efecto la remisión al Liber del Concilio de Coyanza, y se vuelve al régimen sancionador de la tradición canónica con algunas modificaciones. Así, el Decreto de Graciano dispone que el testigo falso eclesiástico reciba la pena de flagelación y tres años de suspensión de oficio, si el testimonio se hubiese depuesto en causa civil, y flagelación y degradación perpetua, si la declaración falsa se hubiese prestado en causa criminal ${ }^{78}$. En la misma línea, las Decretales de Gregorio

74 Las Cortes de León (año 1188) en el reinado de Alfonso IX en su Decreto 19 establecía: “Aquel á quien obier sospecha defiendase por juramento é por agua caliente por mano de omes bonos é verdaderos, é se la querlla fur verdadera é non sospecha pesquiranna omes é verdaderos, é se non podieren trobar verdadera pesquiranna, dien testimonio de ambas partes per tales omes que lo viron é lo oyeron, é aquel que fur vencido, peche por costume de la tierra aquello por que fu dada la querella. E si alguno de las testimonias dixier falso testimonio peche polla falsidat que testimonio LX soldos, ye aquel de quien dixo falso testimonio, pecheye qui quier que ende perdio entregamientre, é las casas de las falsas testimonias derrybenlas, é desde aqui en delantre non sean rrecibidos en testimonio" (Muñoz y Romero, Colección de Fueros Municipales, p. 80).

75 Según entiende Alejandre, el Derecho de la Iglesia, al igual que el secular, en los territorios hispánicos se tuvo que adaptar al nuevo contexto socio-político en los territorios reconquistados, especialmente tras la integración de los nuevos repobladores mozárabes procedentes del sur y portadores del Derecho secular visigodo (Alejandre, "El delito de falsedad testimonial", pp. 67-69).

76 Concilio de Coyanza, Cap. 7,9: Quod ai testes falsi convicti fuerint, illum suplicium accipiant, quod in Libro Judicum de falsis testibus est constitutum. Cito por España Sagrada, Memorias de la Santa Iglesia Exenta de Oviedo concernientes á los siglos X. XI. XII. XIII y XIV, vol. 38, Apéndice I, p. 264.

77 Vid. Alejandre, "El delito de falsedad testimonial", pp. 67-69.

78 Decreto de Graciano, part. II, caus. 5, quest. 6, can. 3. Graciano se limita a reproducir el texto justinianeo de la Novela 123.20: "Reverentissimis autem presbyteris et diaconibus etiam si inventi fuerint pro pecuniaria causa falsum testimonium perhibuisse; sufficiat pro verberibus in tribus annis separam sacro ministerio et monasteriis tradi. Pro criminalibus autem causis si falsum testimonium dixerint, clero nudatos legitimis subdi poenis praecipimus. Reliquos autem omnes in aliis ecclesiasticis ordinibus constitutos, si falsum testimonium cuiuslibet causae sive pecuniariae sive criminalis dixisse convincantur, non solum ecclesiastico officio repelli, 
IX también prescriben degradación perpetua de los hombres de iglesia, cuando éstos perjuraren en causa penal, pues su delito se incluye entre los delitos capitales al igual que el robo o el homicidio ${ }^{79}$. Como veremos posteriormente, el régimen sancionador del Derecho secular coetáneo, acomodado en la costumbre local, se mantiene todavía ajeno al derecho canónico, prescribiendo títulos de punición de los iura propria que pivotan sobre la pena talional y la corporal.

\subsection{Juicio compurgatorio y cojuradores en el ámbito territorial anglo-sajón}

Es a comienzos del s. VII cuando se inicia la actividad de codificación y recopilación escrita del derecho regio, coincidiendo con el proceso de cristianización y con la adopción del alfabeto latino que ofrecía más facilidades para documentar el derecho. Los clanes anglosajonas, herederos del derecho germánico, daban un alto valor a la promesa de cumplir con la palabra dada, elemento nuclear de todo negocio jurídico. Tras la cristianización, la promesa adquiere el valor de fe jurada, la mayor y más efectiva prueba de la reivindicación de un derecho. Por eso, se respetó la presunción de que todo hombre libre decía la verdad, una vez que hubiese prestado juramento ${ }^{80}$.

Las partes en juicio defendían sus causas mediante el juramento compurgatorio, mecanismo procesal también conocido como apuesta por la ley (wager of law). La parte judicial probaba su pretensión aportando el testimonio -que, en realidad, era una ratificación- de conjuradores (oath helpers). Estos testigos de parte se limitaban a dar fe de la veracidad de lo declarado por la parte. Por tanto, no testificaban sobre lo que habían visto y oído, sólo prestaban juramento de credulitate, de modo que el delito de falso testimonio no se producía como consecuencia de una declaración del testigo, sino del acto mismo del juramento de ratificación de la pretensión de la parte. En este contexto, faltar a la verdad jurada no se entendía como una perversión de la acción de la justicia, sino como el quebrantamiento de la promesa dada y una ofensa grave a Dios.

Es posible que las personas libres influyentes cometiesen abusos presentando oath-helpers para defender una reclamación indebida o injusta o exculparse de la comisión de un supuesto delito. Sin embargo, una declaración falsa en nombre de Dios atemorizaba a toda persona de cualquier condición. Por eso, los infractores nobles

sed etiam verberibus subdi" (Cito por la ed. de Schoell y Kroll, Corpus Iuris Civilis: Novellae).

79 Decretales (Gregorio IX), 2,1,10. "Deponendus ergo est Clericus, et degradandus, in furto, homicidio, vel perjurio, sive alio crimine mortali" (cito por Jean de la Coste, In Decretales Gregorii IX).

${ }^{80}$ Así, a finales del s. VII, en las Laws of Wihtrced, el clérigo demostraba su verdad vestido con sus hábitos ante el altar con el juramento Veritatem dico in Christo, non mentior (L. 18); los oficiales del reino exhibían su verdad con la mano sobre el altar y en presencia de otros cuatro administradores reales (L. 19); los nobles y extranjeros nobles podían probar su verdad jurando con su mano sobre el altar (L. 20); el campesino, hombre libre, podía exonerarse de culpa con el juramento sobre el altar de otros cuatro campesinos libres (L. 21). En las Laws of King Alfred, el demandante podía defender la verdad de su pretensión prestando juramento en cuatro iglesias, mientras que para que prosperase la pretensión o la exoneración de culpa del demandado, éste tenía que prestar juramento en doce iglesias. Se presumía que si juraban en falso serían acusados de perjurio múltiple y abocados a la desgracia por invocar la ira de Dios. El código alfrediano tiene numerosas referencias a las leyes del pueblo de Israel en esta materia, Éx. 21:16f y 22:16f; Núm. 25:12-25 y 35:25; y Deut. 1:13f, 19:12f, 22:23f y 24:6-13. En referencia al falso testimonio, se refiere al testigo falso con la fórmula parecida a los diez mandamientos: "Do not witness falsely!". Curiosamente, en el Derecho navarro-aragonés, por ejemplo, el Fuero de Novenera impone al acusador la obligación de jurar su verdad en San Esteban al igual que los "buenos hombres" que testifican contra el acusado. Por su parte, si la acusación no se hubiese probado, el acusado podía deshacerse de la sospecha jurando no haber cometido el delito en las Ribas (Vid. Gibert Sánchez de la Vega, "El Derecho medieval de la Novenera", pp. 1216-1217. 
preferían el juicio por combate antes que jurar en falso su inocencia, mientras que los inculpados de menor condición habrían optado por el juicio de ordalía de agua o fuego ${ }^{81}$.

La autoridad eclesiástica controlaba el juramento promisorio de las partes en los negocios jurídicos contractuales ${ }^{82}$ y estaba igualmente presente en el acto de juramento en causa judicial. Como parte en el acto de juramento y como representante de Dios asumía su competencia para sancionar al perjuro imponiendo pena física de reclusión y ayuno o espiritual de excomunión y exclusión de enterramiento en lugar sagrado. Al contrario de lo que ocurre en los territorios hispánicos de esta época, la iglesia anglosajona, surgida tardíamente tras la conversión de los reinos sajones al cristianismo en el transcurso del s. VII, no desarrolla su propio sistema de tribunales eclesiásticos, precisamente porque es la autoridad religiosa la que interviene al lado del juez real, no solo controlando el acto de juramento de las partes y de los cojuradores, sino porque es el órgano que dispone de los títulos de punición del juramento falso aplicando básicamente las penas de sus Penitenciales, consistentes en períodos de ayuno y penitencia que se plasmaba en la excomunión ${ }^{83}$. Por ejemplo, los penitenciales -El Scriptboc y los Canons of Theodore-sancionan los delitos de adulterio, sodomía, brujería y el perjurio voluntario ${ }^{84}$, involuntario ${ }^{85}$ y venal $^{86}$. En todo caso, la sanción penal quedaba bajo la decisión de la autoridad eclesiástica, que a su arbitrio, decidía el tiempo de "penitencia".

Nótese, por tanto, que en el Derecho secular desde que aparece el primer Código de leyes de los monarcas anglosajones en el s. VII - the Laws of AEthelberht- hasta

81 Whitman, The Origins of Reasonable Doubt, p. 75.

82 Vid. Los Penitenciales anglo-sajones muestran con claridad los lugares y prácticas comunes del juramento promisorio, bien fuese en lugar santo posando la persona obligada su mano sobre objetos consagrados (Old English Scriftboc, 18,1,1 y Old English Canons of Theodore, 76,4,1. en Frantzen (ed.), The Anglo-Saxon Penitentials: A Cultural Database) o sobre la mano de obispo o deácono (Old English Scriftboc, 18,2,1 y Old English Canons of Theodore, 75,4,5. Ejemplos similares, en el continente, figuran en Burchard von Worms, Decretum, 12. Con más detalle, vid. Austin, Shaping Church Law around the Year 1000, pp. 190-196.

83 Como señala Holdsworth, "We expect therefore to find that the church exercised some influence over AngloSaxon law; and more so because, during this period, the close unity between church and state prevented the growth of a separate system of ecclesiastical courts...ecclesiastical canons and secular laws are hardly distinct" (Holdsworth, A History, p. 22).

84 The Anglo-Saxon Penitencials, Laud Misc. 482 (Y42.24.1) fol. 9b (en traducción moderna): "If any layman swears falsely and he knows that he perjures himself, he is to fast 4 years; if he is in minor orders, he is to fast 5 years; if he is a subdeacon, 6 years; a deacon, 7 years; a masspriest, 10 years; a bishop, 12 years". Los Libri Poenitentiales transitaban también en la Hispania visigoda y en el Altomedievo posvisigodo como el Penitencial Silense, el de Córdoba o el Albeldense. En este último, el cap. 6 (f. 188) lleva por título "de periurio et mendacio seu falso testimonio" y contiene, entre otras disposiciones: "Si quis periurauerit VII annis peniteat III ex hiis in pane et aqua (...). Si quis falsitatem conmiserit VII anis peniteat. Qui autem consenserit V. annos peniteat. Si quis periurium fecerit III annos peniteat. Qui ducit alium in periurium ignorantem VII annos peniteat». Vid. Pérez de Urbel y Vázquez de Parga, «Un nuevo penitencial español», p. 27 y González Rivas, La penitencia en la primitiva iglesia española, pp. 189 (texto del penitencial Albendense) y p. 175 (texto del penitencial Silense). Vid. también Fernández Espinar, El falso testimonio, p. 16 y Alejandre, «El delito de falsedad testimonial», p. 72.

85 The Anglo-Saxon Penitencials, Laud Misc. 482 (Y42.24.2) fol. 9b (traducción moderna): "And if anyone is compelled to perjure himself or if he not know it was false, he is to fast 3 years, 1 year on bread and water and 2 as his confessor prescribes for him. And if it is possible for him, he is to free one man for God's love".

86 Idem: "If anyone for fear or love of any man or for any payment swear falsely, he is to give his possessions to needy men and to go to the monastery and repent as his confessor prescribes for him and do penance at all times as long as he lives". Todo parece indicar que el poder regio se mantenía al margen, pues sólo así se justificaría que las Laws of Alfred the Great dictadas en la segunda mitad del s. IX no regulen todavía este delito, limitándose a sancionar al convicto de perjuro que escapa de la prisión de la autoridad eclesiástica. Attemborough, Frederick L., The Laws of the Earliest English Kings, p. 65. 
mediados del s. IX no existe ninguna alusión normativa con relación al falso testimonio judicial.

Al contrario de los "siglos mudos" en los territorios hispánicos, los monarcas anglo-sajones confeccionaron un copioso cuerpo legislativo, recopilando y actualizando su propio Derecho consuetudinario a partir del s. VII. El poder real empieza a desprenderse de las ataduras de la iglesia tardíamente hacia el s. X, en parte porque ésta también busca fortalecer su posición con su aparato jurisdiccional. El monarca del Altomedievo tardío asume ahora su competencia para controlar el juramento en causa judicial en detrimento de la autoridad eclesiástica. Para garantizar su credibilidad la propia ley regia diseña un formalismo rituario y litúrgico para los cojuradores con una tipología de formatos ${ }^{87}$ distintos dependiendo del objeto litigioso del proce$\mathrm{SO}^{88}$.

Los conjuradores (oath helpers) eran hombres libres del lugar o del distrito judicial (Hundred) en el que se habrían producido los hechos y que habrían tenido conocimiento directo de los mismos o de las circunstancias de la disputa de un derecho ${ }^{89}$. El número de conjuradores dependía de la relevancia y entidad de la pretensión o

87 Los formularios documentales se habían generalizado entre los pueblos germánicos. En la época visigótica hispánica se utilizaron estos modelos o fórmulas para la redacción de escrituras y el desarrollo del proceso judicial. Dentro de la colección de las Formulae Wisigothicae destaca el formulario de Ambrosio Morales a fines del s. XVI, que reproduce o elabora de otra copia de la época de Pelayo de Oviedo y que incluye 46 fórmulas supuestamente recogidas por un notario cordobés en el s. VII. Esta colección de Formulas Visigóticas fue publicada por Ureña y Smenjaud, La Legislación Gótico Hispana. Sobre cuestiones relativas a su carácter apócrifo, su uso jurídico o vulgar, etc. vid. Zeumer, Historia de la legislación española, p. 74; Oton Sobrino, "Notas críticas al texto de las Fórmulas visigóticas", pp. 125-130; Schwerin, Claudio, "Sobre las relaciones entre las Fórmulas visigóticas y las andecavenses”, pp. 177-189; Martín Mínguez, Las fórmulas tenidas por visigodas; González Alonso, "La fórmula 'obedézcase pero no se cumpla' en el Derecho castellano de la Baja Edad Media”, pp. 469-487.

88 Diversas fórmulas rituales de juramento figuran en The Laws of Alfred (871-899): L. 13,1: Legitimación de título de propiedad; L. 13,2: Reclamación de ganado robado; L. 13,3: Confirmación de posesión legítima de ganado; L. 13,4: acusación de robo; L. 13,5: Declaración jurada de inocencia (recogemos la fórmula en trad. moderna): "By the Lord, I am guiltless, both in deed and counsel, and of the charge of which (...) accuses me"; L. 13.6: Declaración jurada de los cojuradores: "By the Lord, the oath is clean and unperjured which (...) has sworn". Este protocolo de la formalización del acto de juramento se observaba también en los tribunales eclesiásticos. Vid. con mayor detalle, Moriarty, Eugene J., "Oaths in Ecclesiastical Courts", pp. 22-23.

89 Vid. The Laws of Alfred, L. 13,6. Agustín Prieto hace también referencia a posibles testigos que actuaban como cojuradores en el Derecho leonés. En un Diploma de León de 1056 el testigo parece actuar como cojurador. Igual apreciación se halla en el Fuero de Zamora de 1289, 21: "e por todos juras que omne ovier a jurar con obreros elos obreros que verdad creen que jura aquel con que van jurar" (Prieto Moreira, "El proceso en el Reino de León”, pp. 494-496). Algún estudioso vio en el juramento de cojuradores un instituto similar al juramento de manquadra al que se alude en muchos fueros territoriales (Vid. Riaza Martínez-Osorio y García-Gallo, Manual de Historia del Derecho Español, p. 773). A esta interpretación se ha añadido que la diferencia consistía en que el juramento de manquadra tenía lugar cuando el demandante, que no disponía de pruebas para defender su pretensión, acudía ante el juez con un cojurador (Vid. Mayer, Geschworenengericht und Inquisitionsprozess, pp. 89-90), mientras que algún otro autor entiende que el juramento de manquadra correspondía a la jura de cuatro cojuradores que acompañaban al demandado o al actor [Vid. Granell Muñiz, Ensayos históricojurídicos, pp. 24-26]. Recogiendo el texto de las Partidas $(2,11,23)$ se identificó el juramento de manquadra con el juramento de calumnia del Derecho romano que, según esta teoría, posteriormente se incorporó al derecho canónico pasando finalmente al derecho secular de los pueblos germánicos (Vid. Minguijón Adrián, Salvador, Historia del Derecho español, pp. 35 y ss). Sin embargo, en el Derecho aragonés, el Fuero de Cetina presenta una disposición clarificadora que nos permite constatar que manquadra es el juramento por el cual la parte se compromete a que no litigará por malquerencia (o manquadra). Dicha disposición reza: «Et qui reptaret testimonia, iuret primun quod non demandat manquadra, et postea ipsa testimonia levet ferro» (párraf. 31), vid. ed. Agudo Romeo, «La Carta de Foro Bono de Cetina», p. 46. De ahí que hoy existe cierta coincidencia a extender este instituto procesal al juramento que prestarían las partes en litigio para obligarse a proceder con verdad y sin engaño. Para una evolución conceptual de este instituto, incluidos apuntes etimológicos de la palabra manquadra, vid. García González, «El juramento de manquadra», pp. 211-256, especialmente sugerente es la recopilación de la doctrina sobre esta materia, pp. 214 yss. 
de la gravedad de los cargos en causa penal ${ }^{90}$. Estos testigos de parte lo componían un cuerpo reducido de hombres libres que habían adquirido y acreditado en su comunidad un cierta aura de equidad y solvencia en la resolución de conflictos. Por eso, podían ser propuestos a instancia de parte o convocados por el tribunal (Court). Cuando eran conocedores de la culpabilidad del acusado o de la ilegitimidad de su pretensión aducida no se prestaban a ser cojuradores de parte, obligando de este modo al infractor a que se acogiese al juicio de ordalía.

A partir del siglo $\mathrm{X}$ se empieza a construir un régimen sancionador del delito de falsedad testimonial como delito autónomo e independiente de la autoridad eclesiástica. Así. el rey Athelstan, en la primera mitad del s. X, se reserva el derecho a inhabilitar a perpetuidad al testigo falso, mientras que la autoridad eclesiástica se encarga de aplicar la parte espiritual del castigo prohibiendo al convicto que recibiese sepultura en camposanto por invocar la ira de Dios faltando a la verdad jurada, aunque la propia iglesia, a través del obispo del lugar, permite al reo purgar su culpa con pena pecuniaria ${ }^{91}$. Por su parte, las Laws of King Edward the Elder prescriben que los perjuros o los que prometen bajo falso juramento queden inhabilitados para defender sus derechos y pretensiones por el sistema de apuesta de ley (oath-helping), viéndose obligados al juicio de ordalía ${ }^{92}$. Las Laws of Edmund incluyen en el mismo "tipo" penal a los perjuros y hechiceros, para los que se dicta pena de excomunión, aunque con opción de arrepentimiento y resarcimiento indemnizatorio ${ }^{93}$. Las Laws of Alfred encuadran en el mismo grupo a perjuros, hechiceros y adúlteros reincidentes para los que se dispone que allí donde se hallen sean expulsados del reino, y si permaneciesen, se les dé muerte, a menos que se arrepientan y cumplan la pena eclesiástica ${ }^{94}$.

El régimen sancionador del delito de falso testimonio cambia radicalmente con la invasión y asentamiento escandinavo de Inglaterra en el s. X, especialmente en los territorios ingleses del este en los que se impuso la ley danesa (Danelaw). Estos pueblos invasores germánicos se rigen por su propio ordenamiento jurídico de su lugar de origen. Por eso, cuando finalmente el rey Cnut, bajo el credo cristiano, se hace con el trono inglés en 1017 agrava considerablemente el rigor de las penas y reclama la prevalencia de los tribunales reales sobre los eclesiásticos. Este cambio afectó singularmente a la sanción del delito de falso testimonio, dado que el sistema punitivo anterior de la autoridad eclesiástica (excomunión, ayuno, multas, etc.) es sustituido por la amputación de la mano transgresora del perjuro, la confiscación de

$90 \quad$ El número habitual de cojuradores era de 12, pudiendo variar de 3 a 72. Vid. Pollock y Maitland, The History of English Law, II, p. 601.

912 Æthelstan, c. 26 (en inglés moderno): "And he who shall swear a false oath, and it be made clear against him; that he never after be oath-worthy, nor let him lie within a hallowed burial-place, though he die, unless he have the testimony of the bishop in whose shrift-shire he may be, that he has made such bot as his confessor prescribed to him".

92 Edward the Elder, c. 3 (en inglés moderno): "Also we have ordained concerning those men who were perjurers; if that were made evident, or an oath failed to them, or were out-proved, that they afterwards should not be oath-worthy, but ordeal-worthy".

931 Edmund c. 6: "Those who swear falsely and work lyblac, let them be forever cast out of all commission with God, unless they turn to right repentence" [cito por Thatcher, Oliver, The Library of Original Sources. vol. IV (Early Mediaeval Age), p. 238].

94 Edward and Guthrum, c. 11: "If witches or diviners, perjurers or morth-workers, or foul, defiled, notorious adulteresses, be found anywhere within the land; let them then be driven from the country, and the people cleansed, or let them totally perish within the country, unless they desist, and the more deeply make bot" (cito por Thorpe, Benjamin, Ancient and Institutes of England, vol. I, p. 74). 
la mitad de sus bienes y la inhabilitación perpetua para testificar ${ }^{95}$. Este régimen sancionador es muy similar al que se ha aplicado en muchos ordenamientos territoriales hispánicos no sólo en esta época, sino también en la Baja Edad Media o en otros pueblos germánicos ${ }^{96}$.

\section{El período bajomedieval temprano}

\subsection{La regulación en el Derecho hispánico}

\subsubsection{La adaptación del Liber a los ordenamientos locales}

Los ordenamientos locales del Bajomedievo temprano se limitan a reproducir las disposiciones del Liber Iudiciorum readaptando el régimen sancionador a su costumbre local. Así se justifica que el diverso régimen punitivo surge del distinto grado de antijuridicidad que cada comunidad tiene de este delito y el reproche social de su infractor. Por ejemplo, es posible que en los territorios leoneses se considerase el falso testimonio como un delito de felonía y al testigo falso como un traidor porque lesionaba a la propia comunidad, por eso se le debía desposeer de toda protección jurídica y física, demoliendo su casa ${ }^{97}$. Otros fueros locales leoneses del s. XII y principios del XIII que se redactaron bajo la influencia del Fuero de León, como los de Castrocalbón ${ }^{98} \mathrm{o}$ Villafranca ${ }^{99}$ contemplan una "tipicidad" y un régimen sancionador del delito de falso testimonio muy similar ${ }^{100}$.

952 Cnut, 11,36: "if any one swear a false oath on a relic, and he be convicted let him forfeit his hands, or half his wer and let him that be common to lord and bishop. And let him not be thenceforth oathworthy" (cito por Thorpe, Benjamin, Ancient and Institutes of England, vol. I, p. 399). Vid. Leges Henrici Primi, 11,5,6, ed. Downer, Leslie John, Oxford: Oxford University Press, 1972; y también Pollock \& Maitland, The History, II, p. 540. La amputación de mano se impuso también entre los carolingios para el testigo falso. Vid. Del Giudice, Pascual., "Diritto penale", p. 601. La propia iglesia da su aquiescencia para aplicar pena corporal para extirpar la fuente del mal. Así, aquel perjuro que imprimió la huella de su mano sobre objeto sagrado faltando conscientemente a la verdad, no podía reincidir, por eso se le extirpaban los instrumentos del delito -la mano y la lengua-, que, por otra parte, era un mecanismo de inhabilitación perpetua. Como vamos a ver estos métodos expeditivos de inhabilitación se extendieron por otras partes del continente, concretamente en los territorios hispánicos.

96 Del Giudice, "Diritto penale", I, p. 601.

97 Fuero de León, 19: "Si autem aliquis testium falsum testificasse probatus fuerit, reddat pro falsitate sexaginta solidos, et illi contra quem falsum protulit testimonium, quidquid suo testimonio perdidit, reddat integrum; domusque illius falsi testis dextruatur á fundementis, et deinceps á nullis recipiatur in testimoniis" (cito por Colección de Cortes de los Reynos de León y Castilla, p. 6). Vemos que el Fuero de León mantiene la caracterización del delito que existía en el Liber, pero adapta su régimen sancionador a la realidad de su tiempo incorporando penas infamantes y de exclusión social. En los territorios aragoneses hallamos también la exclusión social del convicto de falso testimonio. Alejandre ("El delito de falsedad testimonial", p. 83) menciona esta prescripción en la Fueros de Aragón, cap. 88: "De homine periuro et probato debet expelli a uicinitate et comunitate aliorum".

98 Vid. también Fuero de Castrocalbón, 4. Vid. Alejandre, "El delito de falsedad testimonial”, p. 83.

99 Fuero de Villafranca, 18: «Si quis probatus fuerit esse falsus testis, pectet LX solidos, et dividantur in III partes ut predic / tum est. Et ipse ex quo falsum testimonium protulerit quicquid suo testimonio alter perdiderit, reddat ei integrum, et domus sua destruatur, et deinceps in testimonium non recipiatur" (cito por González Ramos, "El Fuero de Villafranca del Bierzo", Apéndice documental I, p. 77).

100 La destrucción de la casa del convicto de falso testimonio presenta grandes similitudes con las "Constituciones de exclusión de paz y tregua" de los territorios catalanes de los siglos XII y XIII. Vid. Ferro i Pomà, Victor, "Les constitucions i altres drets de Catalunya”, pp. 183-2002; según este mismo autor, El Dret Públic Catalá, p. 73: "La Pau i Treva, consagrada a alguns usatges i a les constitutions correspondents, elaborades des del segon terç del segle XI fins el començament del XVIII”. Que las Costituciones de paz y tregua estuvieran vigentes hasta el 
La pena de destrucción de la casa del testigo falso convicto debió haberse ejercitado en el Derecho local leonés hasta el s. XIII ${ }^{101}$ a tenor de la previsión que figura en el Fuero de Puebla de Sanabria de 1220 donde se motiva la corrección de la pena de derribo de la casa ante los posibles daños en las edificaciones colindantes, de ahí que se prescriba que se castigue al falsario con una sanción pecuniaria ${ }^{102}$; y en cuanto ocasionó un daño a la víctima debe castigársele con pena talional ${ }^{103}$, pero, además, por faltar al mandato divino y la verdad jurada debe recibir pena corporal (extirpación de la lengua) inhabilitante por perjuro ${ }^{104}$.

Pese a que es cuestionable que exista una normativa del perjurio que lo contemple como un delito individualizado y autónomo en los ordenamientos hispánicos, lo cierto es que hay indicios de su regulación en el Derecho valenciano, en tanto en cuanto no se castiga el perjurio que no se haya cometido en sede judicial ${ }^{105} \mathrm{y}$ especialmente en los Usatges catalanes, pues éstos incluyen la regulación de los delitos de perjurio (cap. 85) y de falso testimonio (cap. 143) con elementos constitutivos del "tipo" penal diferentes y con distinto régimen sancionador. Si consideramos que los ordenamientos territoriales hispáncos no regulan expresamente el perjurio y el falso testimonio como dos conductas punibles diferenciadas, es posible que las dos disposiciones de los Usatges no se hubiesen aplicado en el mismo momento histórico, antecediendo la regulación del perjurio ${ }^{106}$, que podría haber tenido un tratamiento autónomo e independiente inicialmente. De ahí que esta disposición del cap. 85 se complete en el siguiente capítulo 86 con la exigencia del juramento para prestar testimonio. Bien es cierto, que hay motivos para pensar que las disposiciones de los capítulos 85 y 143 estuvieron vigentes simultáneamente por ser compatibles en tanto

s. XVIII es cuestionado por Mansferrer Domingo, La pena de infamia en el Derecho histórico español, p. 196. Este tipo de exclusión social guarda similitud con la pena de outlawry de la época anglosajona que consistía en dejar al convicto fuera de la protección legal de la tribu y, por tanto, sin capacidad de reinsertarse en el propio clan. Al malhechor se le declaraba la guerra, lo que implicaba que cualquier miembro de la tribu tenía no solo el derecho sino también la obligación de perseguirlo, allanar y confiscar sus bienes, darle caza y matarlo como si fuese un lobo (caput gerat lupinum). Esta sanción judicial estuvo vigente al menos hasta el s. XIII para delitos considerados atroces en Inglaterra. Vid. Selected Pleas of the Crown (Selden Society). Year Book 20-1 Edward I, plea 237.

101 La destrucción de la casa, junto con el desprendimiento de su raíz de todo lo sembrado o plantado se halla también el Common Law en esta época, aunque aplicado fundamentalmente a los miembros del jurado que hubiesen dictado verdicto falso. Vid. Henry de Bracton, De Legibus et Consuetudinibus Angliae, c. 1235, fol. 292b (ed. Woodbine, George, Yale University, 1922).

102 Fuero de Sanabria, 17: "Si probado fuere contra alguno que dijo falso testimonio, peche sesenta sueldos, e tenemos por bien que estos sueldos se departan en tres partes: la primera sea dada al Rey, la segunda al conceyo, la tercera a los alcaldes, e torne a aquel contra quien dió el testimonio; e lo que dice en el otro Privilegio que la su casa sea derribada por esta razón, esto no tenemos Nos por guisado, ca esto tornaríe en daño de Nos e de la nuestra Puebla; mas tenemos por bien e por derecho quel tajen la lengua con que dijo el falso testimonio despreciando mandamiento de Dios e mintiendo al alcalde delante quien da el testimonio e queriendo empecer a su vecino ó a otro cualquier por falso testimonio" (cito por Fernández Duro, Cesáreo, "El Fuero de Sanabria", vol. XIII, p. 291). Se intuye que infractor habría atentado al desarrollo normal de la administración de la justicia real, habría despreciado la autoridad del alcalde o juzgador y habría alterado el orden cívico del concejo.

103 Idem: "e torne a aquel contra quien dió el testimonio".

104 Idem: "más tenemos por bien e por derecho quel tajen la lengua con que dijo el falso testimonio despreciando mandamiento de Dios".

105 Alejandre recoge esta prescripción de los Fori Antiqui Valentiae, 62,20: "Probatus vel convictus de periurio non causa testimonio facto penam aliquam civilem vel criminalem non patitur" (mandato que se mantiene en Fori Regni Valentiae, 4,9,54 con Jaime I). Cito por Dualde Serrano, Manuel, Fori Antiqui Valentiae, p. 94. Vid. Alejandre, "El delito de falsedad testimonial", p. 97.

106 Sobre el falso testimonio $v s$ perjurio en los Usatges poco se puede añadir a la extensa y detallada exposición de Alejandre y a su trabajo nos remitimos, de suerte que sólo me limito a resumir escuetamente su argumentación: Alejandre, "El delito de falsedad testimonial", pp. 47 y ss. 
que codificaban conductas delictivas distintas y de desigual gravedad, siendo el perjurio el "tipo" agravado del delito. Sin embargo, admitiendo esta desconexión entre los dos delitos, podríamos intuir que la disposición del cap. 143 pautaría exclusivamente el falso testimonio que no hubiese sido precedido de juramento, empero esta consideración en modo alguno encajaría con la expresión si quilibet...in sacramento comprehendat contenida en dicho precepto. De ello se colige que el falso testimonio depuesto bajo juramento, que es el caso del cap. 143, incluye perjurio, lo que, además, justificaría la sanción de mutilación de la mano transgresora, aquella que se utilizó para colocarla sobre objeto sagrado en el acto del juramento y la extirpación de la lengua no sólo como medio de inhabilitación perpetua, sino como impedimento para utilizarla en nombre de Dios perjurando.

Considerando, por otra parte, que la sanción del perjurio es consecuencia de una declaración falsa prestada bajo juramento, extraña que lo dispuesto en el cap. 85 aparentemente no sancione la declaración falsa, sino el falso juramento, lo que vendría a equipararse a la práctica procesal anglo-sajona del cojuramento de los oath-helpers. Si se acepta que el cap. 85 de los Usatges forma parte de un derecho territorial consuetudinario local antiguo, "un núcleo primitivo" de los Usatges anterior a las leyes de Ramón Berenguer I del $1068^{107}$, es posible que el perjurio se relacionase con el acto de juramento, y no con la declaración que podría haberse limitado también a un tipo de fórmula de cojuramento ${ }^{108}$.

Repárese, no obstante, que el régimen sancionador de los Usatges mantiene claras similitudes con el Liber Iudiciorum ${ }^{109}$ y con el Código Teodosiano ${ }^{110}$. Se establecen presunciones legales - entre ellas, el mayor grado de fiabilidad de los honestiores-y títulos punitivos diferenciados atendiendo al grado de participación en el delito, a los daños ocasionados a la víctima, a las circunstancias del delito y a la condición social del reo (honestior vs. vilior). Se distingue un "tipo" penal básico que sanciona al testigo que jura falso a sabiendas (perjuro), siguiendo la disposición contenida en el cap. 85, con la pena corporal de amputación de mano o pago de una multa de cien sueldos ${ }^{111}$. De facto, la pena corporal sería accesoria para los honestiores y principal para los viliores. El cap. 143 presentaría el "tipo" agravado para el testigo mendaz que faltaba a la verdad jurada por ruego o por precio, siendo sancionado con la anulación de los instrumentos del mal: amputación de la mano pecadora y la extirpación de la lengua supuestamente infame y perversa ${ }^{112}$. Además, a estas penas corporales, que no eran redimibles con el pago de una cantidad pecuniaria, se unía la confiscación de los bienes. Por su parte, el litigante inductor también es sancionado con la pérdida de la causa y la confiscación de bienes muebles que se reparten entre el señor y el erario real ${ }^{113}$. Situación distinta es el resarcimiento de la víctima por

107 Vid. Ficker, Über die "Usatici Barchinonae", pp. 236 y ss, cita que también recoge Alejandre "El delito de falsedad testimonial", p. 46.

108 En el Derecho territorial castellano también figuran fórmulas como “ansi lo juro yo”, o simplemente, Amen (vid. Fuero Viejo de Castilla, 3,2,9, ed. Asso y del Río, Ignacio Jordan de y Manuel y Rodríguez, Miguel de).

109 Lib. (Chindasvinto), 2,4,3.

110 Cod. Theod., 11,14,2.

111 Usatges, cap. 85: "Et si quis convictus fuerit perjurii, manum perdat aut centum solidos redimat" (cito por D’Abadal i Vinyals, Ramón y Valls Taberner, Ferrán, Textes de dret català, p. 38. Vid. también Alejandre, "El delito de falsedad testimonial", p. 46.

112 Usatges, 143:, “et insuper manum amittat et linguam” (cito por D’Abadal i Vinyals, Ramón y Valls Taberner, Ferrán, Textes de dret català, p. 67).

113 Usatges, 143: «...si quilibet testis ab aliquo productus fuerit, in sacramento comprehendat, nec sibi, nec se 
parte del testigo falso. De la literalidad del cap. 162 de los Usatges parece deducirse que cuando el testigo faltaba a la verdad sin dolo no tendría que resarcir a la víctima, indemnizándole el lucro cesante cuando testificaba a sabiendas de su falsedad ${ }^{114}$.

Cuestión más compleja es la "tipicidad" del perjurio extrajudicial. Si nos fijamos en lo dispuesto en el cap. 67 de los Usatges, notamos que se castiga también el perjurio que afecta a la promesa de lealtad, prácticamente con la misma sanción que el perjurio judicial $^{115}$. Sin embargo, la autoridad eclesiástica fue reticente a este tipo de juramento, prohibiendo incluso al clérigo que prestase juramento de fidelidad a un señor laico ${ }^{116}$.

Los ordenamientos locales castellanos de este período bajomedieval temprano contienen una regulación escueta referida a los testigos falsos y un régimen sancionador inicialmente exento de penas corporales. Por ejemplo, el Fuero de Zorita de los Canes dictaba para el que juraba o firmaba declaración falsa una pena pecuniaria equivalente al doble del valor de la cuestión litigiosa junto con inhabilitación perpetua para prestar testimonio y publicidad edictal de su infamia ${ }^{117} \mathrm{y}$, además, pérdida de su oficio, si el infractor fuese juez o alcalde ${ }^{118}$.

sciente, alicui subjecte persone peccunian vel aliam rem fuisse datam vel promissam. Praeterea, falsitatem testium per quos veritati contraria proferuntur omnino compescentes, jubemus, sub examine nostri vel cujuslibet a nobis delegati, littigatem qui scienter falsum testem produxerit vel corrumperit, amissionem causa sustinere, et omnium bonorum mobilium dumtaxat publicacionem incurrere: quorum bonorum medietas domino ipsius assignentur, et medietas erario nostro servetur. Sed eandem penam sustineat circa publicacionem bonorum qui falsum tulisse testimonium convictus fuerit, et insuper manum amittat et linguam" (Ibidem, p. 67). En el citado precepto no se especifica la naturaleza mueble o inmueble de los bienes que son objeto de confiscación. Alejandre, citando a Marquilles, Jacobi, (Commentaria super Usaticis Barchinone, Barchinonis, J. Luschmer, 1505 , fol. $363 \mathrm{v}$ ), "possesionibus" se refiere a los bienes inmuebles ("sedentibus bonis"). Alejandre, "El delito de falsedad testimonial", p. 52.

114 Utsages, 162: "Si quis falsum testimonium contra proximum suum aliquo casu dixerit vel fecerit, tantum de suo avere perdat quantum proximus sus amisisset si veritatem, contra eum testificando, dixisset" (cito por D'Abadal i Vinyals, Ramón y Valls Taberner, Ferrán., Textes de dret català., p. 76. Vid. Alejandre, "El delito de falsedad testimonial", p. 52.

115 Usatges, 67: "Item statuimus ut si quis seniori suo juraverit aliquid quod tenere non curet, dampnum quod seniori suo per transgressione sacramenti evenerit emendet ei in duplo...Si autem et perjurus esse viderit, aut manum perdat, aut centum solidos redimat, aut quartam partem facultatum suarum amittat, proventuram in manu illius cujus perjurus effectus est. Postea non testificatur in placito nec credatur per sacramentum" (cito por D’Abadal i Vinyals, Ramón y Valls Taberner, Ferrán, Textes de dret català., pp 27-28). Vid. Alejandre, "El delito de falsedad testimonial", p. 47). El perjurio como quebrantamiento de la promesa de lealtad estuvo vigente en los territorios ingleses, vid. Mirror of the Justices, cap. 19, ed. Whittaker, William J. Repárese que aún en 1606 Jacobo I, tras sofocar la "Rebelión de la Pólvora" exigió a sus súbditos católicos juramento de fidelidad, cuyo quebrantamiento se consideraba un delito de perjurio y traición.

116 Concilio IV Lateranense de 1215. Vid. Suárez, De iuramento fidelitatis, pp. 484-485.

117 Fuero de Zorita, 813: "Otroquesi mando, que tod aquel que falso testimonio firmare o iurare, peche la petiçión doblada, sicon testigos fuere uençido, et sobre todo esto, en testimonio dalli adelante nunca sea reçebido (a este castigo se añade la pena de infamia) et el su nonbre que sea encartado, quela mala fama de su falsedad mas sea publicada et mas acreçentada, o iure por pleito de su cofradía ode su collaçion. Aquel otroquesi que aotro acusare de falsa iura ode falsa firma, et gelo non pudiere prouar, peche LX menkales alos alcaldes et al querelloso. En el doble del falso testimonio ayan los alcaldes otroquesi parte" (cito por Ureña y Smenjaud, El Fuero de Zorita de los Canes, p. 358). El "encartamiento" ha de entenderse como una publicidad edictal. Entendemos que no existía imposición de marca infamante. No obstante, este Fuero contempla también penas físicas, por ejemplo se dice en la disposición 361: "Si alguno délos andadores por fiel al Rey enbiado fuere, et el iudizio que enla corte del Rey dado fuere, mudare, deue auer la lengua cortada, et pierda todos los bienes que ouiere" (Ibidem, p. 189).

118 Ibidem, 335: "Et si por auentura, el iuez o el alcalde, de mentira o de falsedat depues déla iura uencido fuere, pierda el oficio, o el portielio de conceio, et sobre todo aquesto sea encartado que dende adelante non sea recebido en testimonio. E todo danno quanto por aquella ocasión uiniere, pechelo doblado. Et aquesta misma pena aya el iuez o el alcal- de que verdat escondiere, o otra cosa enterogare alas firmas si no lo queles iudgare, o mentira firmare, o non fuere fiel alconceio, omenospreciare el iudizio del fuero" (Ibidem, pp. 178-179). 
Los fueros locales aragoneses presentan su propia especificidad en el régimen sancionador. Se disponen penas físicas infamantes, como la decalvación en cruces y la marca consistente en la imposición de un badajo ardiente sobre la frente del convicto de falso testimonio ${ }^{119}$.

Más expeditivos son los fueros locales navarros como el de Viguera y Val de Fu$n e s^{120}$ que imponen extirpación de la lengua y pena talional patrimonial. Sorprende el Fuero de Estella de 1164 en el que se dispone que el que acusare de falso testimonio y no pudiera probarlo, compensaría a la víctima también con pena talional patrimonial y su corpus sit in arbitrio Regis ${ }^{121}$. Lo cierto es que esta sanción sería equivalente al membrum et vita del derecho penal medieval inglés, un título de punición que irrogaban los delitos de felonía y traición, para los cuales, atendiendo a las circunstancias del delito y la condición social del reo, el juez, a su arbitrio, podía disponer que se castigase con la mutilación de alguno de sus miembros o con la pena capital del convicto. No obstante, una disposición relativa al falso testimonio prácticamente idéntica a la del Fuero de Estella se halla en el Fuero de San Sebastián, dado por el rey D. Sancho el sabio de Navarra hacia el año 1150. Cambia, no obstante, la locución, corpus sit in arbitrio Regis, que figura en el Fuero de Estella por la de in mercede senioris, terruerit ${ }^{122}$ que se estampa en el Fuero de San Sebastián, lo que vendría a interpretarse que al convicto de falso testimonio se le aplicaría pena arbitraria de tormento.

No debía ser tarea fácil demostrar la deposición falsa de testigo ${ }^{123}$ a la luz de la previsión que figura en el Fuero de San Sebastián, dado por el rey D. Sancho el sabio de Navarra hacia el año 1180, según la cual se requerían supuestamente el testimonio unánime de diez testigos para probar el falso testimonio ${ }^{124}$. Además, el que alegaba falsedad podía verse abocado a ser imputado también de falsedad y recibir la pena de falsos, si no pudiese probar la acusación aducida ${ }^{125}$.

119 Fueros de Aragón, 87: "De testibus falsis. Si probati sunt falsi testes, et iam probati sunt cum aliis testibus, transquirentur in cruces et cum batallo campane calenti crement illos in fronte in cruces, et expellantur a uilla pro falsis et malis». En la misma norma se justifica la marca con el badajo cuando se dicta "quia sicut vox campane auditur per diversa loca ita iniuria et infamia eorum nota sit ubique gentibus". La prescripción 88 de los mismos fueros prevé distinto régimen sancionador para el perjuro: "De homine perjurio et probato debet expelli a uicintate et comunitate aliorum, quia per nihil aliud in tantum perditur fructus mesium et uinearum sicut pro periurio, et peitet" (cito por Ramos Loscertales, "Textos para el estudio del Derecho aragonés", p. 511). Vid. también Alejandre, "El delito de falsedad testimonial", pp. 89 y ss.).

120 Fueros de Viguera y de Val de Funes, 295: (Testigos falsos). "Et si en testimonias fuere fallada falsedat et probada pierdan las lengoas, é de sus bienes enmiendzn todos sus daynnos al quereylloso que ovo por su ocasion dellos con su jura sin torna" (cito por Hergueta, Narciso, "Fueros inéditos de Viguera y de Val de Funes").

121 Fuero de Estella, 28 (versión del s. XIII): "[S]iquis exibit aut perhibebit falsum testimonium, et ille alius contra quem perhibuit falsum testimonium potest probare isti cum idoneis testibus, quod falsum testimonium perhibuit, emendabit ei quicquid per suum falsum testimonium perdidit, et quia falsum testimonium perhibuit, corpus sit in arbitrio Regis" (cito por Lacarra de Miguel, "El Fuero de Estella", p. 440).

122 Fuero de San Sebastián: "et qui fecit testimonium in mercede senioris, terruerit, sed si cum testibus non potest probare, duelum potest se salvare", (cito por Diccionario geográfico-histórico, p. 546).

123 Aunque las Partidas $(3,16,42)$ legitimaban el uso del tormento para el testigo de condición servil que recaía en contradicciones, diferentes fueros, especialmente los aragoneses, prescriben que se ha de probar con testigos. Vid. Fueros de Aragón, cap. 87: "Si probati sunt falsi testes, et etiam probati sunt cum aliis testibus" (cito por Ramos Loscertales, "Textos para el estudio del Derecho aragonés", p. 511); vid. también igual previsión en las diferentes versiones del Fuero de Jaca (A, 236; C, 257 y D, 256).

124 Fuero de San Sebastián: "Si aliquis dixierit, aut fecerit falsum testimonium, et alius potuerit illum probare cum decem testimoniis aliis" (cito por Diccionario geográfico-histórico, p. 546).

125 Fuero de Soria, 279: "Toda firma que firmare falsa mjentre aquella cosa en que non fue njn se açerto o acreçiere en su testimonjo mas de quanto non sopiere, si lo conosçiere el fuere firmado, peche la demanda doblada a aquel contra quien ujniere firmar, e quiten le los dientes e nunca mas uala su testimonio. Esta misma pena (de falso) 


\subsubsection{La configuración del delito en el Ius Commune}

Los glosadores (siglos XII-XIII) anteponían las prescripciones del Ius Commune a las de los iura propria, pero como juristas no tenían capacidad legislativa directa, de modo que su labor fue la de adaptar, actualizar o suplir las lagunas de los iura propria con los nuevos principios del Ius Commune. En gran medida, los ordenamientos locales no desaparecen, sino que se integran dentro del sistema general romano-canónico o adquieren un carácter subsidiario. Lo cierto es que el Ius Commune se incorpora a la actividad legislativa, principalmente en los territorios de la Corona de Castilla en el ámbito civil, pero también en el penal en el transcurso del s. XIII. De modo que la regulación del delito de falsedad testimonial va a sufrir cambios importantes en los nuevos textos normativos surgidos de la conjugación de los los principios inspiradores del Derecho romano-canónico.

El poder regio trata de incorporar nuevos títulos de punición a este delito siguiendo los postulados de un nuevo derecho castellano impregnado de la tradición romanocanónica. Así, el Fuero Real ${ }^{126}$, pese a que algunas poblaciones lo adoptaron como derecho local, se convirtió en Derecho de Castilla y en él se contemplan distintas disposiciones relativas a este delito. Se disponía que el que faltase a la verdad dolosamente y a sabiendas de causar un perjuicio ajeno en causa civil se le impondría la pena talional, -que, por su difícil cuantificación, especialmente en relación al lucro cesante, solía ser arbitraria ${ }^{127}$ - aunque el mismo Fuero Real también prescribe la pena infamante de incapacitación perpetua para ser nuevamente testigo y la pena corporal de extracción de dientes ${ }^{128}$. Con el fin de lograr una mayor cohesión en la aplicación de un derecho penal "general" o territorial, Fernando III ordenó a algunos concejos de la corona de Castilla para que erradicasen el delito de falsedad testimonial, dado que ponía en riesgo la estabilidad de las relaciones jurídicas, y dictando que se impusiese también la pena corporal de extracción de dientes a los que juraren y atestiguaren en falso ${ }^{129}$, lo que se interpretaba que debían abandonar su régimen sancionador local.

aya aquel que demandare a otro en juyzio que firmo falsedat contra el o contra otri, si gelo non pudiere firmar con razon derecha" (cito por Sánchez, Galo, Fueros castellanos de Soria y Alcalá de Henares, Madrid, 1919, p. 102. Vid. también, Fuero General de Navarra, 5,8,2. Aunque hay excepciones como señala Fernández Espinar, El falso testimonio, p. 76, en el que se establece una pena dineraria, como el Fuero de Cuenca, 41,10,11: "Qui alium de falsitate mendaci iurati, vel affirmati accusauerint, nec rem probare potuerit, pectet sexagina menkales alcaldibus" (cito por Ureña y Smenjaud, Rafael, Fuero de Cuenca). La doctrina jurídica ya en la Edad moderna se inclinaba por aplicar la misma pena que recibiría la víctima como consecuencia de la acusación falsa. Vid. Antonio Gómez, Comentario a las Leyes de Toro. Comentario Ley 83, $\mathrm{n}^{\circ} 7$.

126 F.R., 2,8,13: "Qué pena meresce el que dice falso testimonio, ò el que corrompiere à otro para ello. Si algun home dixere falso testimonio contra otro, y despues fuere fallado en falsedad, ò él mismo manifestáre que la dixo; peche á aquel contra quien dixo la falsedad quanto le fizo perder por ella; é si no hubire de qué pechar, sea metido en poder de aquel contra quien dixo la falsedad; é sírvase dél fasta que gelo peche: y el Pleyto en que el testimonio no vala, por decir es falso testimonio, no debe ser desecho" (Cito por El Fuero Real de España, glosado por Alonso Díaz de Montalvo, pp. 243-244).

127 Vid. Alejandre, "El delito de falsedad testimonial", pp. 109-110.

128 F.R., 4, 12, 3: "Todo home que dixere falso testimonio despues que jurare, ò calláre la verdad que supiere, è que fuere demandado, y él dixere despues, que negó la verdad, ò que dixo falsedad, e fuere probado, peche la demanda à aquel que perdió por él, è nunca más vala su tesimonio, è quítenle los dientes: y esta misma haya aquel que aduxere las testimonias para decir falsedad, y ellos si la dixeren". El Fuero de Ayala sanciona también con la extracción de dientes al testigo falso: Ley 3: "que qualquier que sobre juramento que ficiere seyendo prestado en qualquier pleito civil o criminal dijere o depusiere falsamente el contrato de la verdad, e le fuere provado, que le sean escasos de cinco dientes uso, o que el dicho señor sin sus Jueces non le puedan personar esta pena, sin convertirla pena pecuniaria nin en otra pena alguna" (Cito por El Fuero Real de España, glosado por Alonso Díaz de Montalvo, pp. 431-432).

129 Vid. Colección de los antiguos fueros y hazañas de los pueblos de Castilla hechos por Alfonso VII en 1128, II. Tít. 81. 
También el Ius Commune readapta los aspectos procesales de los ordenamientos locales, dando a la prueba testifical un valor esencial, regulando para ello procedimientos para su práctica. El Fuero Viejo de Castilla, por ejemplo, en relación a una causa civil, dispone que "Si un ome demanda a otro (...) deve sacar pesqueridores antel Alcalle, e despues nombrar los testigos, e este juicio deve valer"130. Además, se especifica que el derecho o interés "devegelo probar con vecinos de su vecindat". Asimismo, "si es pleito de eredat, a menester cinco testigos, e si es mueble, a menester dos testigos, e cumpre con ellos"131.

También el Ius Commune formaliza el acto del juramento como un requisito procesal $^{132}$, de suerte que empiezan a figurar explícitamente, en aquellas fuentes normativas que han experimentado la influencia romano-canónica, expresiones del "tipo": despues que iurare ${ }^{133}$ o fore prouado aura iurada falsa iura ${ }^{134}$. El Fuero Real dispone expresamente que "ningún ome sea rescebido en testimonio si non jurare" 135 , e incluso en Las Partidas, siguiendo la técnica procesal del Derecho romano-canónico, se establece un procedimiento del acto de juramento para cristianos, judíos y moros ${ }^{136}$.

$\mathrm{El}$ acto de juramento es previo a la deposición de testimonio ${ }^{137}$, por eso las partes puedan acordar que se dispense de juramento al testigo ${ }^{138}$. Ateniéndose a esta última disposición, todo parece indicar que el texto Alfonsino no preveía reproche penal

130 Fuero Viejo de Castilla, 3,2,1 (cito por Asso y del Río, Ignacio Jordán de y de Manuel y Rodríguez, Miguel, El Fuero Viejo de Castilla, pp. 80-81).

131 Fuero Viejo de Castilla, 3,2,2.

132 En el Derecho castellano hallamos fórmulas rituarias de juramento similares a las utilizadas en Inglaterra con los cojuradores. Vid. el Fuero Viejo de Castilla, 3,2,9 (cito por idem): "jurades a Dios Padre, que fiço el Cielo, e la tierra, e todas las otras cosas, que y son; e a Jesu Cristo suo fijo, e al Espiritu Santo, que son tres personas, e un Dios, que esto que yo vos demande antel' Alcalle, que vos me negades, que vos tal pleito non oviste conmigo?". Respondiendo el que se disponía a jurar: "ansi lo juro yo". En el mismo acto rituario se le advertía "si de verdat sabedes, e mentira jurades, nuestro Senor Dios, a quien lo jurades, vos lo demande en este mundo al cuerpo, e en el otro al anima", respondiendo aquél: “Amen”. La fórmula del juramento podía reiterarse en el mismo acto hasta tres veces: "E puedel demandar otra ves por Dios, o por Santa Maria sua Madre en esta mesma manera. E el devele responder en esta mesma manera. E devele conjurar la tercera vegada"; a lo que siempre el promitente responderá “Amen”. (Idem).

133 F.R., 2,8,13; 4,12,3.

134 Fueros de Aragón, cap. 298: "Itado deue seer de la uilla tot omne contra qui fore prouado que aurá iurada falsa iura, e despues nunqua deue ser recebido en testimonio, ni deue tener officio del rey ni de otro sennor" (cito por Tilander, Gunnar, Fueros de Aragón, p. 175).

135 F.R., 2, 8, 9. Vid. también ibidem, 4,12,3 en que se hace referencia a que el testimonio depuesto sin juramento no cumple las formalidades del proceso. Vid. asimismo Fuero General de Navarra, 172: “ Los homiçieros ni los malfeytores nin los t ladrones manifiestos nin los logradores nin los poçonadores nin los falsos testimonios que son prouados en dito, non son recebidos en testimoniança. Segunt el mandamiento de los buenos homes, los testimonios que han de testimoniar alguna cosa, antes que ren diguan de la cosa, deuen iurar que diran uerdat et non ninguna falsedat" (cito por Martín Duque, Ángel, Fuero General de Navarra, p. 841).

136 Part., 3, 11, 19: "Qvitar deuemos a los omes quanto pudieramos, de contiendas. E porque muchas vezes acaecen, sobre las juras, queremos mostrar cierta manera, enesta ley como deuen jurar los Christianos. E despues mostraremos como deuen jurar los judios, e los moros". No faltan excepciones a la obligatoriedad de juramento que confirmen la regla, vid. Libro de los Fueros de Castilla, 288: "Esto es por fuero de Nagera e de Çereso e de Ryoia: los omnes deuen desir testimonio por juysio del alcalle non deuen ser coniurados, e sin coniuramento deuen desir la testimonia ca vno por sy, estando todos delante; (...) e sy non dixiere el vno commo el otro, non cumple". En términos similares se interpreta la Ley 193 de los mismos fueros: "Esto es por fuero de Çereso: que quien compra heredat deue prouar con seys omnes; e quien compra mueble con tres omnes. Et deue da vno por su cabo estando todos delant el fiel. Et sy yerrare el vno del otro, non cumple" (cito por Sánchez, Galo, Libro de los Fueros de Castilla, p. 156).

137 Part., 3,16,23: "Recebir deue el juzgador la jura de los testigos ante que aya su testimonio (...) Otro si dezimos que ningun testigo non deue ser recebido sin jura".

138 Part., 3,11,28. 
para el testigo que faltaba a la verdad si no había previamente jurado ${ }^{139}$. Pero a diferencia del derecho visigodo (el Liber), las Partidas integran el perjurio en el delito de falso testimonio cuando el testigo prestaba juramento. Caso distinto era el inductor o sobornador, que, pese a no haber prestado juramento, era sancionado con la misma pena que el autor material de la falsedad en el Derecho territorial castellano y vasco siguiendo el precedente romano.

Nótese también que, tras la Recepción, la noción jurídica de falso testimonio evoluciona ${ }^{140}$ paralelamente al desarrollo del concepto de justicia en el ámbito doctrinal, por eso se avanza en la acotación del bien jurídico protegido. Mientras que los ordenamientos locales de los siglos XI-XII se limitaban en general a recoger la sanción que debía aplicarse al que firmaverit, aut iuraverit ${ }^{141}$ un testimonio falso, los textos jurídicos del ámbito territorial castellano del s. XIII amplían el ámbito objetivo del delito de falso testimonio incluyéndose la verdad silenciada ${ }^{142}$, la declaración por exceso afirmando más de lo que se sabe ${ }^{143}$ o la declaración falsa por precio o malquerencia $^{144}$. Así, siguiendo la doctrina de los jurisconsultos del Bajo Imperio romano, la naturaleza jurídica del delito se asienta en las notas de falsedad y mutación dolosa de la realidad. En las Partidas, por ejemplo, es sujeto del delito quien declara falsedad, quien "da precio a otro" para que no declare la verdad "de lo que sabe" o para no dar testimonio, o quien alecciona a los testigos para que declaren falsedad o encubran o nieguen la verdad ${ }^{145}$.

139 Fernández Espinar, El falso testimonio, pp. 53-57, hace una revisión de esta cuestión y llega a esta interpretación, citando algunas otras fuentes normativas de los territorios hispánicos como el Fuero de Tortosa (IV De testibus, costume 1) o el Fuero de las Encartaciones de 1394 y de 1503 o el Fuero de Ayala de 1469. Montalvo, utilizando como fuente normativa el Fuero Real, sostiene que al ser preceptivo el juramento, el que falta a la verdad en juicio no comete el delito de falso testimonio, y se opone al criterio canónico que sostenía Juan Andrés cuando defendía que el testigo que era citado para que diese su testimonio en juicio, pese a que no hubiese jurado, cometía el delito de falso testimonio y debía recibir la pena de falso, pues así lo disponían las leyes divinas, canónicas y civiles (Alfonso Díaz de Montalvo, Glosas al Fuero Real: 4, 12, 2). Según Gregorio López, glosando las Partidas y siguiendo a Bartolo, entendía que las partes podían acordar que los testigos prestasen testimonio sin previo juramento. Siendo así, habría que considerar que los perjuicios que puediese ocasionar la declaración falsa del testigo a la víctima no debería repercutir, al menos de forma talional, sobre el testigo falso. Sin embargo, éste, pese a no haber jurado decir la verdad, actuó con desacato a la autoridad judicial y, en consecuencia, debe recibir pena de falsos (Part., 3, 16, 23, glosada por Gregorio López, Salamanca, 1555).

140 En los ordenamientos históricos hispánicos este delito se ubicó, en general, bajo un Título específico denominado "De las falsedades" que integraba el delito de acusación o denuncia falsas, el falso testimonio, la calumnia, la injuria o la difamación como delitos que afectaban esencialmente al honor de la víctima. Aunque ya en el Bajomedievo se diferenciaban con régimen diferente el perjurio y la calumnia. Vid. las Leyes del Estilo, Ley 136. "Cómo no pueden acusar de perjurio al que juró de calumnia".

141 Fuero de Cuenca, 41,10: "Quicum que falsum testimonium firmauerint, aut iurauerint, pectet"; Fuero de Zorita, 813; Fuero de Teruel, 748, Fuero de Alcázar, fol. 120v; o simplemente al que dijese mentira en causa judicial como en el Fuero de Uclés, 107: "Et de testigos falsos que testimoniaren mentira", y en términos similares, Fueros de Usagre 313: "Tod omne que mentira iurar o firmar"; vid. también Fuero de Cáceres, 294, o Fuero de Coria, 307. Vid. con más detalle estas citas que reseña Fernández Espinar, El falso testimonio, p. 39, notas 69 y 70 .

142 F.R., 4,2,3: "qui dixiere falso testimonio, pues que jurare callare la verdad que sopiere qui fuere demandada".

143 Fuero de Soria, 279: "Toda persona que firmare falsa mientre aquella cosa en que non fue nin se aceto o acreciere en su testimonio mas de quanto non sopiere" (cito por Sánchez, Galo, Fueros castellanos de Soria y Alcalá de Henares, p. 102).

144 Fuero Viejo de Castilla, 167: "que dixo mentira e que lo dixiera por ruego o por dineros o por malquerencia" (cito por Asso y del Río, Ignacio Jordán de y de Manuel y Rodríguez, Miguel, El Fuero Viejo de Castilla, pp. 80-81).

145 Part., 7,7,1: E puedese fazer la falsedad en muchas maneras (...) E aun la fase el que es llamdo por testigo en algun pleyto, di dixere falso testimonio, o negare la verdad, sabiéndola. Eso mismo faze el que da precio a otro, porque non diga su testimonio en algun pleyto, de lo que sabe. Otrosí lo faze, el que lo recibe, e non quiere decir su testimonio porende, ca tambien el que lo da, como el que lo da, como el que lo recibe, ambos fazen falsedad. 
Sigiendo también la jurisprudencia de los juriconsultos del Bajo Imperio romano, la "tipicidad" se constituía mediando dolo, pero no necesariamente con perjuicio ajeno. Las recurrentes expresiones, "a sabiendas"146, "non dixo que lo sabía"147, no nos aclaran si se refiere al hecho de que el testimonio emitido contrario a la verdad o alterando la verdad de lo percibido de forma instintiva sin ánimo doloso carece de reproche penal, o si por el contrario, si el dolo conlleva necesariamente una conducta que tenga un destinatario al que se le causa un perjuicio. El Fuero Real vincula el falso testimonio a la deposición realizada "contra otro" (una de las partes en la cau$\left.\mathrm{sa}^{148}\right)$. En todo caso, también en el propio Fuero Real hallamos prescripciones del "tipo" genérico como "Todo ome que dixere falso testimonio"149 y en las Partidas es significativo que se podría actuar de oficio "si fallase algún testigo por falso en el testimonio que diere" 150 sin que se especifique la exigencia de perjuicio ajeno.

Otro elemento constitutivo del "tipo" que acaba fortaleciéndose con el Ius Commune es la realización efectiva o la consumación de la conducta transgresora. Se ha puesto de manifiesto que en el derecho histórico medieval (y moderno) la pena se determina para hechos delictivos que reúnan los elementos constitutivos de "consumación perfecta cometida con ánimo doloso"151. Acotando esta presunción al delito de falsedad testimonial, observamos efectivamente que se repiten en las fuentes hispánicas medievales locales y las de ámbito territorial o general de cada reino expresiones perfectivas, que ya figuraban en los textos bíblicos ${ }^{152}$ como "fuere fallado" 153 , "fuere probado"154 "fuer probado"155, "le pudieren provar que firmó mentira"156, etc. También el conato o la tentativa de falso testimonio podía integrarse en el "tipo". Aunque en el Derecho histórico la ley penal "describe" y sanciona "el crimen perfecto"157, y no "situaciones intermedias o ejecuciones imperfectas" 158 , no es óbice para que el juez imponga pena arbitraria para el conato o la tentativa de delinquir en atención a la "cualidad del conato" o la gravedad del delito que se pretenda cometer.

\subsection{La desaparición de la prueba testifical en el proceso judicial inglés}

Enrique II en el s. XII impulsó un procedimiento de resolución de conflictos civiles, por el cual doce hombres libres recibían el encargo de indagar, esclarecer, presentar y evaluar los hechos. En este nuevo contexto judicial, los miembros del jurado son

Otrosi dezimos, que qualquier ome, que muestra maliciosamente a los testigos en que manera digan testimonio con intención de los corromper, porque encubran la verdad, o que la niquen, que faze falsedad..."

146 Part: : 3, 11, 26: “...le pudiren provar que juro mentira a sabiendas” 3, 16, 42; 7, 1, 1 y 7, 1, 6.

147 Part., 7,7,1.

148 F.R., 2, 8, 13. Recordemos que también el Liber Iudiciorum sólo castigaba expresamente la declaración contraria al reo o a una de las partes, aunque después de Ervigio parece haberse eliminado esta limitación (Lib., 2, 4. 8 y $2,4.10)$.

149 F.R., 4, 12,3.

$150 \quad$ Part., 8, 1, 38; 3, 2, 26 y 7, 1, 26.

151 Ortego Gil, Pedro, "Notas históricas", p. 421.

152 Vid. Deut. 19, 16-21.

153 F.R., 2, 8, 13.

154 F.R., 4, 12, 3.

155 F.R., 4, 12, 3.

156 Espéculo, 5,2,30; Part.: 3,11,26: “...le pudiren provar que juro mentira a sabiendas”; vid. también ibidem, $3,16,42 ; 7,1,1$ y $7,1,6$.

157 Ortego, "Notas históricas", p. 421.

158 Ibidem, p. 428. 
los encargados de obtener las pruebas y de indagar sobre hechos acaecidos con los medios a su alcance. Para ello se podrían desplazar incluso al lugar de la comisión del delito para interrogar a los posibles testigos del acto delictivo o de la controversia en litigio. El virtual testimonio falso depuesto por estos lugareños, testigos directos de los hechos, ante los pesquisidores o miembros del jurado en sus lugares de residencia o trabajo no constituía ningún delito, pues su declaración no se había prestado en sede judicial bajo juramento.

Lo relevante, a efectos de este estudio, es que los miembros del jurado son ahora los testigos ${ }^{159}$-indirectos-y los jueces de los hechos ${ }^{160}$, y en consecuencia, los únicos sujetos de un potencial delito de falsedad testimonial en su explicación y presentación de las pruebas en juicio. Por tanto, la conducta constitutiva de falso testimonio se produce en realidad en una fase preprocesal, en el curso de la averiguación de los hechos que torticeramente conducen a un verdicto falso.

El poder regio no reguló con una ley específica (Statute) el delito de falsedad testimonial de los miembros del jurado, considerando que las previsiones del Common Law eran suficientes para atajar el improbable delito de personas libres ${ }^{161}$, dado que no se esperaba de todos ellos connivencia para pronunciar un veredicto con aportación de pruebas falsas. Lo cierto es que, en aplicación del Common Law, si se demostraba que los miembros del jurado habían sido conniventes en dictar veredicto contra la realidad de los hechos, se les sancionaba con la pérdida de la protección jurídica de hombres libres (amittere liberam legem ${ }^{162}$ ). Este castigo de degradación al acatamiento de la justicia de los villanos acarreaba la pena de infamia -inhabilitación para ejercer de miembro de un jurado o de testigo en causa judicial- confiscación perpetua de bienes muebles e inmuebles, desprendimiento de su raíz de todos sus sembrados y árboles, demolición de sus casas ${ }^{163}$ y a todo ello se unía la pena de prisión ${ }^{164}$.

159 Vid. MacNair, "The origins of the Jury", pp. 537-599. Los miembros del jurado son los nuevos actores que testifican (testare; así se recoge en los Northumberland Assize Rolls, plea 72: "et iuratores testantur quod"), los que reconocen, investigan y examinan los hechos directamente, vid. Select Pleas of the Crown, pl. 20 (1202): "Et hoc offert probare...sicut ille qui non vidit hoc sed per alios habet eum suspectum. Nullum est appellum" Vid. Pollock y Maitland, The History, II. p. 622. Respecto a una mayor concreción de la función del jurado en el Bajomedievo inglés, vid. Baker, Introduction to English Legal History, pp. 86-90; De Groot, "The Jury of Presentment before 1215", pp. 1-24 y Klerman, "Was the Jury ever Self-Informing?", pp. 123-149.

160 Thomas More en 1533 sostiene que los, "jurors were not be regarded as witnesses, but as judges of fact." (Guy, Keen, Miller, y Mcgugan, The Complete Works of St. Thomas More, pp. 1xviii-xciv). Thomas More responde así a Christopher St. German, respecto a la pregunta de qué tipo de testigos podían dar testimonio en los juicios en casos de herejía. Para Thomas More sería más efectivo un sistema procesal inquisitorial que condujese al acusado de herejía a la purgatio, antes que que un jurado juzgase los hechos (Idem, pp. liii-lvii).

161 El Gran Jurado (Grand Assize) lo componían 12 hombres libres elegidos por cuatro knights que a su vez habían sido elegidos por el Sheriff del condado, mientras que el Jurado Ordinario (Petty Assize) lo componían también doce hombres libres de la vecindad elegidos directamente por el Sheriff del condado "per quos rei veritas melius sciatur" (Pollock \& Maitland, The History, II. p. 621) o, según Bracton, entre los "qui melius sciant et velint veritatem dicere" (Bracton, De Legibus, f. 316.). Parece que no era suficiente la condición social de hombre libre como requisito habilitante, se requería también un determinado nivel socio-económico de modo que se inhabilitaba al hombre libre por su conocida "pobreza", vid. Select Civil Pleas (1200-1203), London: Selden Society, 1890, pl. 126, 253: "Therefore it is ordered that other jurors be elected, because [the first jurors] are paupers and unworthy".

162 La sancion penal de liberam legem amittere implicaba "To lose one's free law, (called the villainous judgment) to become discredited or disabled as juror and witness, to forfeit goods and chattels and lands for life, to have those lands wasted, houses razed, trees rooted up, and one's body committed to prison. It was anciently pronounced against conspirators" (Crabb, A History of English Law, p. 319).

163 La sanción de destrucción de la casa para el delito de falsedad testimonial figura también, como ya se mencionó, en los fueros leoneses de Castrocalbón, Villavicencio y Villafranca.

164 No obstante, Ranulf de Glanvill señaló que en la práctica se libraban del castigo con pingües multas (Tractatus 
Por su parte, el Britton, compendio del Common Law de la segunda mitad del s. XIII, equiparaba el delito de falsedad de veredicto del jurado con el delito de homicidio alevoso y premeditado sancionado con la pena talional corporal o capital a la que habría sido condenada la víctima como consecuencia del veredicto falso ${ }^{165}$. Por otra parte, el Common Law sancionaba como un supuesto agravado el veredicto pronunciado mediando dádiva o soborno ${ }^{166}$. La revisión del veredicto requería en todo caso el nombramiento de un nuevo jurado, esta vez compuesto por 24 miembros ${ }^{167}$, que podía anular el veredicto de los 12 miembros anteriores ${ }^{168}$.

La pugna jurisdiccional entre los tribunales eclesiásticos y la jurisdicción real para enjuiciar el delito de perjurio persiste en los territorios ingleses en los siglos XII y XIII. Considerando que en el acto de juramento la persona empeñaba su fe de salvación dando en prenda su cristiandad a la autoridad divina, sólo a los representantes de este poder eterno le correspondía la sanción de aquellos que quebrantaban la fe jurada, así como la gestión de su arrepentimiento a que todo hombre tenía derecho ${ }^{169}$. El conflicto de foro se agrava principalmente por la impunidad de los hombres de iglesia y la atenuación progresiva de las penas en los tribunales eclesiásticos pasando de la excomunión y/o la exclusión de enterramiento en lugar sagrado a la simple inhabilitación perpetua para prestar juramento ante los tribunales eclesiásticos ${ }^{170}$.

Las Constituciones de Clarendon de 1166 dan impulso a la justicia real para reclamar su competencia para juzgar las infracciones graves cometidas por clérigos que hasta entonces estaban sólo sujetos a la jurisdicción eclesiástica que preveía para los ellos castigos de escaso rigor punitivo como la flagelación, multas, excomunión o pérdida de hábitos. Las Constituciones de Clarendon determinan que el clérigo sea juzgado ante los tribunales eclesiásticos para que dirimiesen sobre su culpabilidad. Si el clérigo era culpable, el propio tribunal eclesiástico lo despojaría de sus hábitos, al tiempo que el oficial de la justicia real, presente en la causa, lo conduciría a los los tribunales del rey, de modo que el acusado, ya desposeído de sus hábitos, podía ser juzgado y sancionado por su delito como un convicto laico ${ }^{171}$. No obstante, la iglesia se opuso a esta doble condena por el mismo delito, exigiendo que la "degradación"

de legibus et consuetudinibus regni Angliae, 1188, II. 19). Si el veredicto había sido dictado con ignorancia negligente de los hechos, los miembros del jurado quedaban también exentos de culpabilidad, vid. Bracton, De Legibus, fol. 289 y fol. 292 y Britton, II, 228 (ed. Nichols, Francis M., Oxford: Oxford University Press, 1865).

165 Vid. Britton, 34-35: (Serán acusados de homicidio alevoso) "those who falsely for hire, or any other manner, have condemned, or caused to be condemned any man to death by means of false oath; ... and let their judgment be death for death" (ed. Nichols). Vid. también The Mirror of Justices, 144 (ed. Whittaker): (Se distingue el perjurio "mortal" y "venial") "in the case of mortal perjury there is mortal judgment, as in the case of open homicide"; ib. 23: "homicides in will are also false jurors, false witnesses, and those who appeal others or defame them by indictment, or in other ways accuse persons falsely so that it is not their fault that death does not follow"; $i b$. 137: (los miembros del jurado que presentan los hechos faltando a la verdad -al igual que los jueces que con argumentos falsos condenan a muerte a una persona- "should be adjudged to be hanged". Vid. también Hogan, "Murder by perjury", pp. 285-286.

166 Bracton, De Legibus, fol. 289. See also fol. 292, and Britton, II. 228.

167 GlanvilL, Tractatus de legibus, II. 19 y Bracton, De Legibus, fol. 292b.

168 Glanvill, idem.

169 Bracton, De Legibus, f. 290 b y Britton, II. 227; Vid. Merchant, The Church under Law, p. 45; vid. también, Hughes, "Witnesses", p. 31.

170 Hughes, "Witnesses", p. 23

171 Es conocida la disputa entre Enrique II y Thomas Becket respecto a si los tribunales del rey debían juzgar a los clérigos que habían cometido delitos fuera del ámbito eclesiástico. Dice el rey: "primo Deum et (ut dici solet) Christianitatem suam obsidem dabat; deinde patruum suum...et omnes qui convenerant constituebat fideiussores" (Letters of John of Salisbury, ed. Giles, Constable, vol. II, p. 224; vid. Pollock \& Maitland, The History, II. p. 191). 
fuese castigo suficiente para el primer delito, lo que se conoce como "beneficio del clero".

El conflicto jurisdiccional de foro tuvo especial incidencia en asuntos de deudas y transacciones de bienes ${ }^{172}$. El contrato era un acto de fe jurada, conque el incumplimiento contractual se convertía en causa fidei laesionis seu perjurii y, en consecuencia, el tribunal eclesiástico demandaba su competencia ${ }^{173}$. Sin embargo, el poder real se impuso y en las Constituciones de Clarendon de 1164 se dictó que los "placita de debitis, quae fide interposita debentur, vel absque interpositione fidei, sint in justitia regis" 174 . Un siglo más tarde Enrique III fue más contundente y dictó un Decreto en 1247 prohibiendo a la jurisdicción eclesiástica enjuiciar asuntos "de catallis et debitis, nisi sint de testament vel matrimonio" 175 , pese a que el foro eclesiástico seguía considerándose competente para dirimir super perjurio et fides laesione en causas civiles $^{176}$.

Pese a la reiterada oposición de la jurisdicción eclesiástica a ser desplazada de su competencia para juzgar de peccatis aut excessibus subjectores sicut de perjurio, Enrique III en el año 1260 dispuso que su jurisdicción conocería del delito de perjurio $^{177}$. Aun cuando este conflicto de foro tuvo su mayor acritud a mediados del s. XIII, parece que se impuso un cierto consenso, que pervivió hasta finales del s. $\mathrm{XV}$, en virtud del cual la jurisdicción eclesiástica seguía conociendo causas de fides laesionis et perjurii de menor cuantía en juicios sumarísimos en los que se imponía la pena de pago de la deuda pendiente sub pena sententiae excommunicationis ${ }^{178}$.

172 El Year Book 11 Henry IV, p. 88, recoge el conflicto de foro entre la jurisdicción real y eclesiástica para dirimir un caso de perjurio. El poder real impone su jurisdicción aduciendo que la causa principal (sobre derechos reales) es de su competencia. Vid. Stephen, The History of Criminal Law, III, pp. 243-244.

173 Flahiff, George B., "The Writ of Prohibition", p. 278.

174 Stubbs (ed.), Select Charters, p. 140.

175 Orden de prohibición a la jurisdicción eclesiástica de inmiscuirse en asuntos "de catallis et debitis, nisi sint de testament vel matrimonio" cuyo tenor literal es: "lites de fidei laesione et perjurio prohibentur a rege, quando super his conveniuntur laici coram judice ecclesiastico. Prohibetur ecclesiasticus judex tractare omnes causas contra laicos, nisi sunt de matrimonio, vel testamento" (Matthaei Parisiensis, Chronica Majora, ed. Luard, Henry R., London: Rolls Series, 57, 1877, IV, p. 614).

176 Vid. Annales Monasterii de Burton, año 1237: "Item, lici faciunt clamare Londoniae voce praeconia, nequis tractet causam in for ecclesiae, sive de perjurio, sive de fide laesa, de usura vel simonia, vel defamatione, nisi tantum super testamento et matrimonio, et prosequentes hujusmodi causas incarcerant". (en Annales Monastici, ed. Luard, Henry R., I. p. 256); Véase, a mayor abundamiento, otro extracto de los mismos Anales del año 1257: "Ordinarii judices ad quarelam laici de laico feodo, vel catillis, non cognoscant; si tamen hujusmodi fide data vel sacramento adhibito, de fidei transgressione seu sacramenti violatione, per inquisitionem, sive per facti evidentiam seu alio modo legitime constiterit, mortaliter sic peccans legitime commonitus, ad condignum poenitentiam agendam compellatur" (Ibidem, p. 406). La misma reivindicación se produce en el Concilium Mertonense, año 1258: "Sane, cum nulli clerici adinvicem et plerumque cum clericis contrahentes, ipsos contratus fidei datione vallent, aut corporaliter praestito sacramento, qui super fidei aut sacramenti prestiti religione contempta coram judice ecclesiastico conventi, regam prohibitionem impetraveri, ut super perjurio et fidei laesione examen ecclesiastici judicis declinent”, ed. Wilkins, Concilia magnae, vol. I, p. 738. Vid. también Concilium Lombothense, año 1261: "Aut pro eo quod ecclesias dedicavit, vel ordines celebravit, aut de causis mere spiritualibus cognovits, ut puta de decimus, oblationibus, limitibus parochiarum, et similibus, quae non possunt ad secular forum aliquatenus pertinare: aut quia cognivit de peccatis, et excessibus subditorum; sicut de perjurio, et fidei transgresione" (ed. Wilkins, Concilia magnae, p. 747). Vid. Gordon, "The Perjury", p. 442. Estos extractos se mencionan también en el estudio de Flahiff, “The Writ of Prohibition”, pp. 298-299.

177 "de peccatis subdit congnoscunt Prellati absque impedimento Regis exceptis casibus in quibus intendant per hoc indirecte in foro ecclesiastico aliquid quod ad forum Regis ad ejus pertinet jurisdiccionem De perjurio et fidei violatione idem intelligat". Vid. Woodcock, Medieval Ecclesiastical, pp. 89-91. Vid. también Gordon, "The Perjury", p. 442.

178 El número de causas interpuestas por este delito de "fides laesionis et perjurii” fue muy escaso. Por ejemplo, entre los 158 casos enjuiciados en el Consistory Court of Canterbury en el año 1474, sólo se enjuiciaron dos casos por perjurio (Woodcock, Medieval Ecclesiastical, p. 78); vid. asimismo Gordon, "The perjury", p. 442 


\section{El período bajomedieval tardío}

\subsection{Configuración del "tipo" penal y régimen sancionador en los ordenamien- tos locales y territoriales hispánicos}

En el Bajomedievo tardío, los comentaristas del Ius Commune, como Bartolo de Sassoferrato, interesados en resolver cuestiones litigiosas planteadas en la práctica judicial, revirtieron la preeminencia del Ius Commune de los glosadores de los siglos anteriores (XII-XIII) y aplican ahora en los siglos XIV y XV el principio ubi cessat statutum, habet locum ius civile. En consecuencia, el ius municipale, especialmente cuando éste se integra en el seno del derecho territorial "general" recopilado de uno reino, se revitaliza en la Baja Edad media tardía, de suerte que en caso de conflicto entre el Ius Commune y los ordenamientos municipales o territoriales, prevalecerá la norma estatutaria local o la territorial recopilada. En todo caso, si la norma estatutaria no daba respuesta satisfactoria a la cuestión debatida, el Derecho común suplía estas deficiencias, convirtiéndose ahora en norma supletoria. En este contexto, el delito de falsedad testimonial va a tener acogida en los ordenamientos territoriales con su propia regulación sustantiva, procesal y con su propio régimen sancionador.

Cabe reseñar, en primer lugar, que el delito de falsedad testimonial en cuanto que afectaba a la esfera privada, su persecución se efectuaba a instancia de parte ${ }^{179}$, aunque ya se empiezan a introducir nuevas vías de incoación de un proceso para dirimir un caso de falso testimonio. En efecto, algunos ordenamientos locales del siglo XII como el de Uclés o el de Viguera, o el de Usagre en s. XIII hacen referencia a la potestad de la autoridad judicial para ordenar su persecución ${ }^{180}$, siendo más patente, no obstante, en los ordenamientos de ámbito general territorial castellano, por ejemplo, en las Partidas ${ }^{181}$ o en la Leyes del Estilo ${ }^{182}$.

Si no se abría un nuevo proceso a instancia de parte, habrá que entender que el juez, a su arbitrio y en base a simples indicios ${ }^{183}$, determinaba que el testigo declaraba una falsedad. Montalvo, ya en los albores de la Edad Moderna sostenía que el juez sólo estaba habilitado para actuar de oficio cuando en el transcurso de un proceso detectase la falsedad imponiéndole al testigo la pena de falso en el mismo proceso principal, porque al terminarse el proceso sólo cabía entablar acción a ins-

179 La denuncia exclusivamente de parte parece desprenderse de los fueros de Cuenca, 41. 10; Zorita, 813; Teruel, 748 o Alcázar, fol. 120v.

180 Recoge los textos Fernández Espinar, El falso testimonio, p. 66.

181 Part., 3, 16, 42: "Otrosi decimos que si ellos pudieran saber que los testigos que han sido presentados ante ellos, dijeren o dicen falso testimonio, o que encubren a sabiendas la verdad que aunque otro no les acuse de ello, que los jueces los puedan escarmentar y darles pena, según crean que merecen”. Igualmente, Part. 7, 1, 38 (en referencia a que "yerros" puede "el rey o juez de su oficio escarmentar, maguer no fuesse fecha denunciación, nin acusamiento, nin fuesse fama en razón dellos"): "El segundo, si fallase algun testigo por falso en el testimonio que dixere ante el".

182 Leyes del Estilo, 115.

183 El juez podía atormentar al testigo que caía en diferentes versiones o contradicciones en la apreciación de los hechos; Part., 3, 16, 42: "Otorgamos por esta ley lleno poderio a todos los Judgadores que han poder de fazer justicia, que quando entendieren que los testigos que aduzen ante ellos van desuariando sus palabras o cambiándolas, si fueren viles omes aquellos que esto fizieren, que los puedan tormentar, de guisa que puedan sacar la verdad dellos". El uso del tormento aparece ya en la época Justiniano (Novela, 90, 1). 
tancia de parte ${ }^{184}$. Los comentaristas de las Partidas $^{185}$ también divergen respecto a la competencia del juez que ha de dirimir un supuesto en el que el testigo depuso su declaración falsa ante un juez comisionado en otra localidad distinta a aquella en que se enjuicia la causa principal. Gregorio López, al contrario de Baldo ${ }^{186}$, considera que tanto el juez de la causa principal como el comisionado son competentes para enjuiciar y sancionar a los testigos ...que fueren aduchos ante ellos ${ }^{187}$. Aun así, surge el problema de qué pena ha de imponer el juez comisionado. Pues bien, habrá que entender que si se aísla al testigo para su sanción de la causa principal, solo le podría imponer pena extraordinaria o pena arbitraria ${ }^{188}$.

Algunos fueros vascos, sobre los cuales el Derecho castellano irradió su influencia, especialmente en el régimen sancionador, también contemplaban la persecución de oficio, puesto que regulaban un procedimiento especial al efecto ${ }^{189}$, determinándose expresamente que el juez no puede "entender" ni "proceder" "contra el tal Testigo, salvo durante el Pleyto, en que depuso el Tal Testigo, et no depues de sentenciado (el pleito): Salvo si antes de la Sentencia comenzare a proceder contra el dicho falso Testigo", pues en este caso, se puede enjuiciar al acusado de falso testimonio "en todo tiempo", esto es, antes o después de haberse dictado resolución de la causa principal $^{190}$.

Como se ha reseñado, al inicio de este epígrafe, los ordenamientos municipales y territoriales -generales- de cada reino adquieren carácter preferente de aplicación en la Baja Edad Media tardía frente al Ius Commune que se utiliza como norma supletoria. Pues bien, a continuación haremos una breve revisión del régimen sancionador de este delito en los diferentes territorios hispánicos.

Los ordenamientos de ámbito general castellanos mantienen la pena talional cuando el testimonio falso provoca la imposición de una pena corporal o capital a la víctima, castigo que habría de recaer también sobre el testigo falso si la sanción ya se

184 Montalvo, Glosas al Fuero Real: 4,12,3. Montalvo, sin embargo, cita a Juán Andrés, aduciendo que éste cree que el juez puede actuar de oficio contra el testigo falso después de concluir la causa principal en la que cometió delito de falsedad testimonial. Vid. Fernández Espinar, El falso testimonio, pp. 67-68.

185 Part., 3, 16, 42.

186 Baldo de Ubaldi, Decretales, I, 14.

187 Gregorio López en el comentario a Part., 13, 16, 42 señala que si bien "No podrá, pues, castigar á los testigos falsos el juez delegado, ante quien hubieren aquellos declarado (...) ni juez que solo tenga jurisdicción en causas civiles". Sin embargo, entiende Gregorio López que esta posición no puede defenderse para el caso de la Ley 42 de la Partida que comenta, pues de la expresión (testigos) "que fueren aduchos ante ellos" se colige que tiene jurisdicción aquel juez "ante quien ha delinquido" el testigo falso.

188 Fernández Espinar, R., El falso testimonio, p. 83.

189 El Fuero de Ayala (Aumento del Mariscal D. García López de Ayala de 1469) dispone, en referencia al castigo de testigos falsos y sobornadores, Ley 3: "el dicho Señor e sus jueces puedan proceder a los castigar e punir de su oficio o a querella de parte" (cito por Uriarte y Lebario, Luis Ma de, El Fuero de Ayala, p. 220). Más explícita es la Ley 2 ("En que manera se puede proceder contra los testigos falsos") del título VIII de Fueros, Privilegios, Franquezas y Libertades de Vizcaya, donde se dice expresamente que el "Juez puede proceder de oficio contra Testigos falsos, e sobornadores, e corrompedores de ellos, cuya falsedad estuviere averiguada por el Processo" (cito por Fueros, Privilegios, Franquezas y Libertades de Vizcaya, pp. 73-74). Al mismo tiempo prevé dicha disposición que la falsedad la puede descubrir el juez en el transcurso del proceso por confession e variedad, e contrariedad del Testigo" (idem); dejando abierta la forma por la cual el juez podría averiguar la falsedad del testigo -"en otra qualquier manera" (idem)-, lo que no es descartable que el juzgador tuviese la potestad de aplicar tortura como ya lo disponían las Partidas $(3,16,42 ; 7,1,1$ y 7, 1, 6). Esta Ley 2 del Título VIII de Fueros, Franquezas y Libertades de Vizcaya también establece unas garantías para probar la falsedad del testigo, pues se prohíbe que se hagan (fuera del contexto del proceso de la causa principal) "nueva probanza para averiguar la falsedad, salvo por experiencia de el Lugar, y evidencia et vista ocular, et reproducimiento y acarreamiento de Testigos" (cito por Fueros, Privilegios, Franquezas y Libertades de Vizcaya, pp. 73-74).

190 Fueros, Franquezas y Libertades de Vizcaya, idem. 
hubiere ejecutado en la persona del reo ${ }^{191}$, incluso, a inicios de la era moderna las Leyes de Toro, también preveían esta pena talional aunque la condena no se hubiese ejecutado en la víctima, pues, por el falsario, "no quedó de dársela"192, ni de contravenir y menospreciar las "buenas costumbres y la autoridad judicial" ${ }^{193}$. En el Espéculo, -todavía poco romanizado- a la pena talional se acumulaban sanciones del Derecho propio como la imposición en la cara en sitio visible de una marca infamante a hierro candente, junto con la inhabilitación perpetua ${ }^{194}$. Por su parte, el Fuero Real configura un régimen sancionador talional, inhabilitación y pena corporal de extracción de dientes ${ }^{195}$ y que se extiende a los territorios vascos ${ }^{196}$. Estas penas físicas (marcado o extracción de dientes), procedentes de la costumbre local, se imponen sólo al falsario perjuro, porque la falsedad no jurada se castiga sólo con pena talional compensatoria. Sin embargo, las Partidas, diferenciando causa civil y penal ${ }^{197}$, sancionaban al infractor con pena dineraria de cuantía fija y variable quedando al arbitrio judicial cuantificarla apreciando el daño causado y el lucro cesante ${ }^{198}$. Se abría así una larga tradición punitiva de este delito asentada en el arbitrium iudicis.

Igualmente, las Leyes del Estilo sancionaban el delito de falso testimonio con pena arbitraria que el Alcalde aplicaría "según su albedrío" si se probase que el testigo había actuado mediando dádiva o soborno ${ }^{199}$. Curiosamente en la Ley 115 se diferencia el delito de falso testimonio y de perjurio, estableciéndose que, para el

191 Espéculo, 5, 11, 30: "E si por su testimonio fuere alguno muerto o lisiado, que reciba él mismo otra tal pena." (Cito por Opúsculos legales del rey Don Alfonso El Sabio, t. I., p. 416).

192 Leyes de Toro, 83: "Cuando se probare que algun testigo depuso falsamente contra alguna persona ó personas en alguna causa criminal, en la cual si no se averiguase su dicho ser falso, aquel ó aquellos contra quien depuso, merescia pena de muerte, ú otra pena corporal; que al testigo averiguándose como fue falso, le sea dada la misma pena en su persona y bienes, como se le debiera dar á aquel, ó aquellos contra quien depuso, seyendo su dicho verdadero, caso que en aquellos contra quien depuso no se ejecute la tal pena, pues por él no quedó de dársela...". (cito por, Llamas y Molina, Sancho, Comentario crítico, p. 566). Esta Ley 83 se reproduce en la Nueva Recopilación $(8,17,4)$ y a la Novísima $(12,6,4)$.

193 Gregorio López, glosando la "pena de falso" (Part. 3, 11, 26) y preguntándose cómo se habría de punir al testigo falso que no ocasiona daño a la víctima ("Et quid si testis falsus non sit utilis producenti, nec adversario nocens?"), responde siguiendo el criterio de Baldo: "Baldus dicit quod adhuc punitur, quia delinquit contra bonos mores, et aures iudicis offendit".

194 Espéculo 5, 11, 30: Mas si alguno fuere aducho por testigo, e despues que oviere jurado le podieren provar que firmó mentira, debe pechar a aquel contra quien firmó todo quanto perdió por su testimonio, e demás devenle fazer senal en la cara, en logar que lo non pueda encobrir, con un fierro caliente, que sea fecho en la manera que dize en el título de las penas. E si por su testimonio fuere alguno muerto o lisiado, que reciba él mismo otra tal pena. (...), es por ende perjuro, e a por pena que debe ser dado por malo e non ser creydo en ningún testimonio, nin ser par de otro" (cito por Opúsculos legales, pp. 416-417).

195 F.R., 2, 8 13: "Si algun ome dixere falso testimonio contra otro y despues fuere fallado en la falsedad o el mismo manifestare que la dixo; peche a aquel contra quien dixo la falsedad quanto le fizo perder por ella; e si no hubiere de que lo pechar, sea metido en poder de aquel contra quien dixo la falsedad, e sirvase del falsta que xelo peche y el pleyto en que el testimonió no vala. Ibidem, 4, 12, 3: "Todo home que dixere falso testimonio despues que jurare o callare la verdad que supiere, e que fuere demandado, y él dixere despues que negó la verdad o que dixo falsedad e fuere probado, peche la demanda a aquel que la perdió por él, e nunca más vala su tesimonio, e quítenle los dientes, y esta misma pena haya aquel que aduxiere las testimonias para decir falsedad, y ellos si la dixeren" (Cito por El Fuero Real de España, glosado por Alonso Díaz de Montalvo).

196 Cuaderno de la Hermandad de Vizcaya de 1393, 33: (quien) "juró decir verdad, que la encobrió e non dixo que lo sabía, que por este encubrimiento que así fizo e non decía lo que sabía o decía mentira en decir más de aquello que sabía verdad" (...) o quien "induce al testigo que diga lo que non debe decir o encubrir la verdad de lo que sabe" (vid. Galíndez Suárez, Jesús, La legislación penal de Vizcaya, Bilbao, 1934). Esta redacción del Tít. 33 es similar a la que figura en las Partidas $(3,16,42$ y $6,7,1)$ y en el F.R. $(4,12,3)$ y se extiende a otros ordenamientos vascos y navarros. Vid. con mayor detalle, Alejandre, "El delito de falsedad testimonial", pp. 109-110.

197 Part. 3, 2, 26

198 Part., 7, 7, 1.

199 Leyes del Estilo, 115. 
caso de perjurio, el Alcalde, según su albedrío, podía imponer de oficio, sin petición de parte, la pena de falsos ${ }^{200}$.

En el Derecho territorial navarro-aragonés el falso testimonio se sanciona con el destierro, - cuyo ámbito de exclusión territorial varía según las fuentes normativas-y la pena infamante de inhabilitación ${ }^{201}$. El exilio ya figuraba en algunos fueros locales, como el de Alfambra del s. XII. Era un destierro de carácter temporal, a veces limitado a los días en que se prohibía jurar ${ }^{202}$. No obstante, se mantiene, con arraigo en la costumbre, la marca infamante de decalvación en cruces e impresión de señalamiento con el badajo candente de una campana ${ }^{203}$.

En el Derecho de Navarra, el Amejoramiento de 1331 se aleja del Derecho castellano cuando dispone que se endurezcan las penas existentes para el testigo falso (decalvación en cruces, impresión de marca y destierro) dictando la horca en causa criminal y mutilación de lengua en causa civil ${ }^{204}$.

Otras fuentes de ámbito local, como el Ordenamiento sobre administración de justicia otorgado a Sevilla en 1360 por Pedro I, establecen penas de carácter recaudatorio para aquellas personas que incurran en falso testimonio y "que el derecho pone como honradas" y de los que se presupone que pueden pagar la cuantía fija de "seiscientos maravedís" 205 . Este tipo de pena pecuniaria como instrumento recaudatorio para el testigo falso la dispuso también el Rey Alfonso XI ordenando que se ingresase en la Cámara del Rey las multas por la pena de quien jurase en falso sobre la Cruz y los Santos Evangelios ${ }^{206}$.

200 Idem

201 Fueros de Aragón, cap. 298: "Itado deue ser de la uilla tot omne contra qui fore prouado que aura iurada falsa iura, e depues nunqua deue ser recebido en testimonio, ni deue tener officio del rey ni de otro sennor" (cito por Tilander, Gunnar, Fueros de Aragón, p. 175).

202 Fuero de Alfambra, 138. Se prohibe prestar juramento, salvo en juicio, desde finales de mayo al 15 de agosto. Lo que habrá de entenderse como una prevención de comisión de perjurio en época de recogida de cosechas para evitar la ofensa a Dios y de este modo su castigo. Vid. Albareda y Herrera, El Fuero de Alfambra, p. 95. Vid. también el Fuero General de Navarra, 2.7.2: "Nuill omne non deve iurar de septuagessima atta X días de Pascoa de curesma passados. Otrossi, en adviento non debe iurar ata la fiesta de Sant Illarii passada. Otrossi del dia de Santa Cruz de mayo al tercero día de San Miguel non debe iurar, si non fuere por homizidio o por traycion ó por onta" (cito por Ilarregui, Pablo y Lapuerta, Segundo, Fuero General de Navarra, p. 32).

203 Fueros de Aragón, 87: "De testibus falsis. Si probati sunt falsi testes, et etiam probati sunt cum aliis testibus, transquirentur in cruces et cum batallo campane calenti crement illos in fronte in cruces, et expellantur a uilla pro falsis et malis" (cito por Ramos Loscertales, “Textos para el estudio del Derecho aragonés, p. 511).

204 Fuero General de Navarra, Apéndices: Amejoramiento de 1331, cap. 4

205 Vid. Ordenamiento sobre administración de justicia dado por Pedro I a Sevilla en 1360, Ley 12: "por ende, despues que fuere fecha esta jua, mando que el juez de su ofiçio pregunte por este articulo la verdat a amas las partes, si fuere despues provado o mostrado por el proçeso del pleito que juro mentira alguno dellos, mando que si este que asi juro mentira es de las personas quel derecho pone por honradas que pague el pleito en así juro mal seisçientos maravedís desde moneda para el muro de la villa y para las calçadas della, e por el segundo pleito en que asi juro mentira que sea desterrado fuera de Sevilla e de su termino e del arçobispado de Sevilla por quatro annos; e si fuere de las personas menores, que por el primero pleito en que juro mentira quel den veinte açotes, e que por el segundo pleito en que jurare mentira quel doblen esta pena e por el terçero pleito que asi jurare mentira quel den çiento açotes e lo destierren de Sevilla e de su arçobispado por quatro annos" (cito por Sáez, Emilio, "Ordenamiento sobre administración de justicia dado por Pedro I a Sevilla en 1360", pp. 725-726). Curiosamente, no se prescribe inhabilitación.

206 Ordenamiento de la Cámara del Rey, Don Alfonso XI, Ley 10: "Todo onbre que jura falso, en la Cruz e en los Santos Evangelios, e les provado non cree en la Fe, e debe, pechar seiscientos maravedís para la Camara del Rey” (cito por Cerdá Ruiz-Funes, Joaquín, "Dos ordenamientos sobre las penas pecuniarias para la Cámara del Rey (Alfonso XI y Enrique III”, p. 454). Igualmente en el Ordenamiento del Rey D. Enrique III. Ley 11: “Toda persona de qualquier ley que fuer, e jurare falso en su ley, debe pechar seiscientos maravedís para la mi cámara a mas que le sean quintados los dientes antel pueblo" (cito por ibidem, p. 462). Vid. Fernández Espinar, R., El falso testimonio, p. 19, notas 30 y 32. Posteriormente, la multa para sancionar al testigo falso se incorpora a las Ordenanzas Reales de Castilla (N. Rec, 8,17,2) y a la Nov. Recopilación (Nov. Rec, 12,6,1). 
En el Derecho de valenciano, hasta el reinado de Jaime I, se sancionaba al autor material del delito de falsedad testimonial con pena talional -compensando a la víctima con el daño efectivo sufrido - junto con el abono de otra cantidad igual para la $\mathrm{Cu}$ ria; penas éstas que se acompañaban con la inhabilitación para prestar testimonio ${ }^{207}$. Esta regulación tenía dificultades en su aplicación en los casos en los que el infractor careciese de recursos, por eso en el propio reinado de Jaime I se añadió una nueva disposición por la que se establecía - para los infractores que no podían compensar en su totalidad a la víctima y a la Curia- una pena subsidiaria, consistente en las penas físicas de perforación de la lengua con hierro ardiente y de azotes por las calles de la ciudad $^{208}$. Iguales penas habrían de ser aplicadas para el inductor o el sobornador ${ }^{209}$. Jaime II en 1301 mantiene estas sanciones, añadiendo la pena corporal de mutilación de mano y de lengua ${ }^{210}$ para el supuesto en que se hubiese ejecutado pena corporal a la víctima del falso testimonio. Finalmente, las penas se acaban endureciendo en el transcurso del s. XIV, de modo que una Constitución otorgada por Jaime III en 1336 dispuso que el falso testimonio depuesto en causa civil se sancionase con amputación de la lengua y destierro perpetuo y en causa penal, independientemente de la suerte que le hubiese ocurrido al reo, se castigase con la pena capital ${ }^{211}$.

En suma, en el Bajo Medievo tardío, es recurrente la pena física (extirpación de lengua, extracción de dientes, enclavado de lengua, decalvación) junto con la inhabilitación para ser nuevamente testigo en la mayoría de los fueros municipales y territoriales hispánicos. No obstante, cada territorio aplicaba sus propios castigos físicos. Por ejemplo, como ya hemos mencionado, la extracción de dientes se aplica esencialmente en los territorios castellanos y vascos. Nótese, sin embargo, que cuando las Partidas se imponen en los diferentes territorios, la sanción del testigo falso queda al arbitrio del juez ${ }^{212}$.

207 Fori Antiquae Valentiae, 62,19: "Probatus de falso testimonio perdat de bonis suis tantum quantum est illud, de quo fecerit falsum testimonium, si alius pro suo testimonio aliquid amisit; et, ultra hoc, pro pena solvat curie tantum quantum est medietas illius super quo falsum testimonium fecit, et nunquam testimonium recipiatur" (Cito por Dualde Serrano, Manuel, Fori Antiquae Valentiae, p. 94). Vid. Alejandre, "El delito de falsedad testimonial", p. 124.

208 Fori Regni Valentiae, 4,9,55:“Addentes huic foco quod si ille, qui tulit falsum testimonium, non habebit unde posit satisfacere, secundum quod supra dicitur, eius lingua cum ferro calido perforetur, et per villam fustigetur" (Dualde Serrano, Manuel, Fori Antiquae Valentiae, p. 94) incluye este texto, vid. también. Alejandre, "El delito de falsedad testimonial", p. 124.

209 Fori Regni Valentiae, 4,9,54: "Aquell qui haura preses diners o hauer daltres, perço qui faça testimony en lo seo pleyt, perda aytant quant haura rebut e alter tant. E aquell qui aquell hauer li haura donat perda aytant de mes del seu com a aquell haura donat. E aquell qui haura press hauer daltre, perço que no face testimoni contra ell que pach aquell hauer en doble, e james no tinga offici de vila ne pusque ese reebut per testimoni" (cito por Alejandre, "El delito de falsedad testimonial", p. 124).

210 Ibidem, 4, 9, 56. Jaime II:’E si en feyt criminal del qual se pogues es degúes pena corporal enseguir fara falç testimoni per alsolre o condempnar alcun altre pusque prouat li sera que haja feyt falç sagrament o testimoni perda la ma ab que haura feyt lo falç sagrament, e la lengua ab la qual haura dit lo falç testimoni" (cito por ibidem). Estas penas corporales se aplicaron en las postrimerías de la Baja Edad Media. Según los datos obtenidos del estudio de Emilia Salvador Esteban ("Tortura y penas corporales", pp. 274 y ss) en la Valencia foral de la época de Fernando el Católico 9 reos sufrieron la amputación de una mano y dos la de ambas, mientras que a 7 se les penalizó con el clavado de la lengua, aunque desconocemos el tipo de delito al que se aplicaron estas penas físicas.

211 Vid. Sanxo y Vicens, Antichs privilegis y franqueses del regne, p. 27.

212 Part., 3, 16, 42. 


\subsection{El perjurio de los miembros del jurado en los territorios ingleses}

Al contrario de los territorios hispánicos, en el Bajomedievo tardío el monarca inglés imparte la misma justicia regia en toda Inglaterra a través de sus jueces reales itinerantes, quienes armonizan la aplicación de la ley regia con el uso y el precedente judicial en cada distrito judicial (Hundred), creándose de este modo las bases del Common Law. En este nuevo contexto judicial basado en la costumbre y en el precedente contencioso, el Common Law disponía de instrumentos de derecho sustantivo y rituario para sancionar el perjurio sin necesidad de que el Parlamento tuviese que promulgar una ley (Statute) específica para atajar el delito.

El compendio normativo Mirror of Justices sigue considerando el perjurio judicial y el que quebranta la promesa jurada de lealtad ${ }^{213}$ como un pecado que atenta esencialmente a la autoridad divina. En causa penal el perjurio es un delito unemen$d a b l e^{214}$ que entra en la misma categoría penal del homicidio alevoso, merecedor de la pena capital, si, como consecuencia de la actuación falsaria, se condena y ejecuta al reo inocente ${ }^{215}$. Si éste no fuese condenado a muerte, el perjuro sufriría el castigo de demolición de su casa, el exterminio de sus sembrados y bosques (sin confiscación) y destierro temporal o perpetuo ${ }^{216}$. En causa civil, el falsario sería sancionado con pena corporal de mutilación, que podía evitarla con el pago de una multa y con la reparación plena de la víctima del perjurio ${ }^{217}$.

Recordemos que el perjurio judicial quedaría restringido a los miembros del jurado que, en el ejercicio de sus funciones, hubiesen aportado pruebas falsas o dictado veredicto falso. Es sabido que en el Bajomedievo el falso testimonio del testigo $\mathrm{u}$ observador directo de los hechos en el transcurso de un proceso, generalmente en la fase preprocesal o de instrucción, no tendría sanción penal en el Common Law ${ }^{218}$.

213 Mirror of the Justices, 39 (ed. Whittaker).

214 El perjurio se asimila al homicidio alevoso o culposo para determinar la pena aplicable porque, al contrario de los ordenamientos hispánicos en los que se asigna una pena a una conducta, en los territorios ingleses ya desde las Leges Henrici Primi de 1115, los delitos se clasifican en enmendables (emendable) o redimibles con pena pecuniaria y no enmendables (unemendable).

215 Mirror of Justices, 19 (ed. Whittaker): "In the case of mortal perjury there is mortal judgment, as in the case of open homicide".

216 Idem: "And for venial perjury those convicted may be condemned to exile for years or for ever, and their woods, meadows, houses, and gardens may be destroyed as though they were homicides, but their heirs will not be disinherited".

217 Idem: "And note that in all personal actions [entered as tortious] at the suit of the party, the judgment is that due satisfaction be made to the plaintiff, and that the sinners be punished by a corporal punishment, which can be redeemed by a ransom in money".

218 Holdsworth, A History, III, 1927, p. 401:"There are some clear statements in the cases decided in the sixteenth century that perjury by a witness was not punishable by the common law". Ya en el s. XIV, en el caso Onslowe (Dyer, II. 242b, 73 English Reports 537 (S.C. 1565) o en el caso el caso Damport v. Sympson (Cro. Eliz. 520, 78 English Reports 769 (K.B. 1596) los jueces concluyeron que el Common Law no sancionaba el perjurio o falso testimonio de testigo en juicio. Respecto al caso Onslowe, dice Hudson que "all the judges assembled at Serjeants Inn read the statutes of 3 Hen. VII, c. I, and II Hen. VII, c. 25, and the proviso for the Star Chamber in stat. 5 Eliz., c. 9, and concluded that perjury could not be tried in the Star Chamber, because stat. 3 Hen. VII, c. I, 'does not provide any punishment for perjury any more than it does for murder although it is mentioned in the preamble to follow maintenance and others the misdemeanors first recited', while stat. n Hen. VII, c. 25, would have been unnecessary if provision had already been made for the punishment of perjury" (Dyer, II. 243a, 73 English Reports 537 (S.C. 1565). Refiriéndose a este caso, Hudson expresa su sorpresa respecto a la decisión de los jueces declarando: "I dare undertake to show them, that the common law of England had a punishment for perjury before the Conqueror". Sin embargo, el propio Hudson considera que en su época el perjurio de testigo incluido el que pueda originar la condena a muerte de un inocente no debe penalizarse, ni tampoco examinar si lo hubo, porque los posibles testigos, temiendo ser objeto de sanción, no testificarían perdiéndose la oportunidad 
En este contexto bajomedieval en el que delito y pecado se confunden es natural que perviviese el conflicto jurisdiccional entre el poder real y el eclesiástico. Sin embargo, de forma más o menos pacífica el juez real se consideró competente para enjuiciar aquellos supuestos en los que la voluntad de los miembros del jurado estaba viciada por dádiva, enemistad o promesa, pues, aun siendo un pecado por faltar a la verdad jurada, también era un delito público ${ }^{219}$, en cuanto que se ofendía a la comunidad. Esta nueva concepción del bien jurídico protegido ante la actuación del falsario adquiere sustantividad aún a partir del s. XVI, coincidiendo con una ampliación del ámbito objetivo y subjetivo del delito de falso testimonio en los territorios anglosajones, especialmente con la promulgación de la ACT for the Punyshement of suche persones as shall procure or commit any wyllfull Perjurye ${ }^{220}$ de 1563 que viene a complementar la regulación general del Common Law. Con esta Ley comienza a configurarse el falso testimonio como un delito contra la Administración de Justicia mucho antes que en los ordenamientos continentales. Así, ya Pollock y Maitland ${ }^{221}$, en referencia al s. XIII, incluyen al perjurio entre los delitos de transgresión (trespass) fraudulenta "of the machinery of the law" $\mathrm{y}$ William Blackstone ${ }^{222}$ en el último tercio del s. XVIII incluye el perjurio bajo la rúbrica "Of offences against public justice".

Obvia reseñar que el "tipo" penal de perjurio requería la exigencia de juramento $^{223}$. Como sostiene algún autor, en los tribunales ingleses no se daba crédito a ninguna persona, por muy alto rango social, moral o noble del que fuese acreedora, si no prestaba juramento ${ }^{224}$. Sólo se excluía de la obligatoriedad del juramento a aquel testigo que acudía a juicio, generalmente a instancia de parte o del jurado, de modo que su potencial declaración falsa ya no entraría en la categoría de delito perjurio, sino de delito menor (msdemeanour) ${ }^{225}$.

Como es obvio, otro de los elementos definitorios de la "tipicidad" era el dolo que se recoge en el aforismo reiterado en la doctrina de la época moderna: "a vicious act requieres a vicious will". Por eso, para tipificar el falso testimonio como delito deben coexistir dos elementos: una declaración voluntaria y libre hecha por un testigo en proceso judicial bajo juramento a sabiendas de que su declaración es falsa ${ }^{226}$. Esta configuración del perjurio la resume con gran precisión Fletcher cuando lo define: "perjurium est mendacium cum iuramento" 227 . Ya en el s. XVII, Edward Coke man-

de obtener pruebas en juicio ("Another perjury not punishable, nor emuinable, is perjury committed against the fife of a man for felony or murder whereof the party accused is convicted by verdict and judgment (...) lest it should bring a scandal upon the public justice of the kingdom, if the cause of a person so convicted should receive new examination" (Hudson, "Court of Star Chamber" pp. 72 y 81). Hogan ("Murder by perjury", p. 288), menciona también el caso Damport v. Sympson en el Star-Chamber con la misma conclusión: el Common Law no sanciona el perjurio de testigos.

219 La noción de perjurio como "pecado público" figura en diferentes fuentes normativas más tardías. La pragmática de 1500 de los Reyes Católicos se ordena perseguir y condenar a "los amancebados y testigos falsos y otros pecados públicos"

220 Statute 5 Elizabeth c. 9.

221 Pollock \& Maitland, The History, II. p. 519.

222 Blackstone, Commentaries on the Laws, IV, pp. 136-140.

223 Leges Henrici Primi, c. 5, s. 28 (ed. Downer): “iuramentum debet habere comites ueritatem iustitiam et iudicium; si ista defuerint non iuramentum set periurium erit".

224 Caso Meers vs Lord Stourton 1. P. Will. 146 o el caso Lord Shaftesbury vs. Lord Digby, 2 Mod. 146. Vid. Peake, Thomas, Compendium of the Law of Evidence, London: W.T. Clarke, 1922, pp. 11-12.

225 Ibidem, p. 12.

226 Gordon, "The Perjury", p. 440.

227 Vid. el caso Parsons vs Herne (Febrero 6, 1593, S. C), en Hawarde, John, Les Reportes Del Cases, p. 6. Vid. 
tiene este principio básico de que el delito sólo existe cuando el testigo depone a sabiendas testimonio falso en causa judicial y en asunto al que el testimonio afecta directamente $^{228}$.

Respecto a la consumación del delito, la práctica forense se basa en el aforismo jurídico, "actus non facit reum nisi sit rea". El adagio se remonta en la tradición anglo-normanda a las Leges Henrici Primi ${ }^{229}$ en el s. XII, aunque Pollock y Maitland sostienen que ya S. Agustín, al referirse al falso testimonio, lo había enunciado cuando dice "ream linguam non facit nisi mens rea"230.

Para observar el grado de percepción de la sociedad y de las instituciones de la antijuridicidad de este delito habría que acudir a la práctica judicial de la época. De forma muy fragmentada, hemos observado que los Year Books registran 22.318 causas de la Curia Central de Westminster (Common Pleas Court) entre 1268 a 1525. En sólo 18 causas figura la acusación de parte de perjurio y 201 litigios de acusación de falso juramento (false oath). Sin embargo, no existe ninguna causa principal, iniciada en proceso separado, por false oath o perjury ${ }^{231}$, aunque se instruyen causas en las que se debaten resoluciones judiciales injustas o de prisión improcedente como consecuencia de un veredicto falso. En estos casos implícitamente se cuestionaba el posible perjurio de los miembros del jurado. Hemos de concluir, pues, que la persecución del perjurio tuvo que ser muy limitada, además, a instancia de parte con el riesgo de que el denunciante, si no lo probaba, sería acusado de denuncia y acusación falsa. De ahí que habría que convenir con Pollock y Maitland cundo afirman, en referencia a todo el Medievo inglés: "our ancestors perjured themselves with impunity"232.

\section{Conclusión}

El régimen jurídico del delito de falso testimonio en la época visigótica se establece en el Liber Iudiciorum que regula un "tipo" básico (declaración falsa voluntaria) y un "tipo" agravado para el falsario que actúa por inducción, siguiendo los elementos constitutivos del ilícito previstos ya en la Lex Romana Visigothorum, que, a su vez, integra las notas definitorias del "tipo" descritas por Paulo en el Bajo Imperio romano (falsedad manifiesta y dolo). El bien jurídico protegido es el interés de la víctima vulnerado o puesto en riesgo, pues, el falso testimonio se concibe como una violación que afecta a la esfera privada y, por tanto, sólo a instancia de parte se ha de perseguir. El Liber no contempla sanciones corporales, optando por la confiscación, inhabilitación para deponer nuevo testimonio y degradación a la condición de siervo de la víctima para el infractor que no pudiese resarcir. En este primer subperíodo Altomedievo temprano-en los territorios anglo-sajones, hasta comienzos del s. VII no se inicia la actividad de codificación y recopilación escrita del derecho regio.

\footnotetext{
Gordon, "The Perjury", p. 440.

228 Coke, Institutes of the Lawes, p. 164.

229 Leges Henrici Primi, c. 5. v. 28 (ed. Downer).

230 San Agustín, Sermones, 180, c. 2.

231 Por ejemplo, el Year Book 11 Henry IV, p. 88, n 40 recoge el conflicto de foro entre la jurisdicción real y eclesiástica para dirimir un caso de perjurio en un asunto de herencia y posesión de predio. Se veta a la jurisdicción eclesiástica por tratarse de perjurio que afectaba a un proceso en cuya causa principal se dirimía un asunto de derechos reales, competencia de la jurisdicción real.

232 Pollock \& Maitland, The History, cit., II, p. 543.
} 
Existe evidencia de que el documento privado no se incorporó al tráfico jurídico hasta los albores de la Baja Edad Media, de modo que los derechos y privilegios, los acuerdos entre particulares o clanes, las deudas contraídas, etc. se acreditaban en juicio por medio de testigos de parte (oath-helpers). El instrumento punitivo que reprimía la conducta de un testigo falso era la venganza de sangre (blood-feud) o la exclusión social del clan junto con la confiscación de su patrimonio (outlawry).

Por su parte, el Derecho conciliar canónico mantenía su propio régimen jurídico con las notas distintivas del "tipo" penal diseñadas por los jurisconsultos del Bajo Imperio romano y el Derecho justinianeo. El régimen sancionador se circunscribía a la pena de excomunión temporal o perpetua y la exclusión del clero como prescripción de carácter general. La autoridad eclesiástica, a su arbitrio, impone el tiempo por el que se dicta la sanción. Se abre paso así al arbitrio judicial derivándose siglos más tarde al Derecho secular (véase las Partidas) tras la recepción del Ius Commune.

Por lo que respecta Altomedievo tardío posvisigótico, los territorios hispánicos reconquistados aplicaban su propio derecho local para la regulación de este delito, basado en la costumbre, aunque el Liber pervive readaptándose a la costumbre local. Pese a la incertidumbre del cauce procesal de este delito -juicio compurgatorio, duelo judicial u ordalía-, es posible que el inculpado noble se habría acogido al riepto, mientras que el infractor de baja condición social optaría por la ordalía, si no encontraba testigos que avalasen su inocencia para defenderse en un juicio compurgatorio. En cambio, en los territorios ingleses del Altomedievo tardío prevalecía el juicio compurgatorio de conjuradores. Estos testigos de parte no testificaban sobre lo que habían visto y oído, sino que se limitaban a dar fe de la veracidad de lo declarado por la parte en juicio. Por tanto, la potencial "falsedad testifical" no constituía un delito de falso testimonio, en tanto que no existía una declaración del testigo, sino una violación del juramento sagrado. En este contexto, faltar a la verdad jurada era simplemente un acto de perjurio, de ahí que la autoridad religiosa controlase el acto de juramento de las partes y de los cojuradores y, a diferencia de las fuentes normativas hispánicas, el poder eclesiástico se arrogaba los títulos de punición del juramento falso aplicando básicamente las penas de sus Penitenciales. Así pues, el juez real juzga y sentencia y la iglesia gestiona la pena (reclusión, ayuno, excomunión o resarcimiento pecuniario). Tras la invasión escandinava en el s. X se incorporan nuevos instrumentos legislativos y títulos punitivos, que afectan a la regulación del delito de falso testimonio, incidiendo de forma especial en el régimen sancionador, al incorporase a la tipología de penas la mutilación de miembro, en este caso, la mano transgresora que se había posado sobre objeto sagrado en el acto de juramento.

En el Atomedievo tardío, la Iglesia hispánica era incapaz de establecer una legislación uniforme en los territorios reconquistados. La autoridad eclesiástica local se regía fundamentalmente por la costumbre, por los textos conciliares o por el $\mathrm{Li}$ ber para la regulación sustantiva y procesal del delito de falsedad testimonial. Para uniformar la regulación de este delito, la Iglesia optó, en el Concilio de Coyanza de 1055, por la aplicación de las disposiciones del Liber Iudiciorum.

Los territorios hispánicos del Bajo Medievo temprano y tardío se dotan de sus propios fueros municipales y prácticamente en todos ellos se recoge una regulación del delito de falso testimonio. Tras la recepción del Ius Commune se van imponiendo nuevos instrumentos normativos con alcance territorial más extenso y con mayor grado de irradiación hasta el punto de que el Ius Commune adquiere carácter preeminente especialmente en la segunda mitad del XIII, sin embargo en los siglos 
XIV y XV los fueros municipales y territoriales recuperan vitalidad, al menos en la regulación de este delito. Por su parte, el Decreto de Graciano, seguido de las Decretales de Gregorio IX, recuperan la tradición canónica alejándose del Liber a partir de mediados del s. XII.

El juramento previo a la deposición se considera, en general, un requisito procesal de carácter invalidante. No obstante, el juramento se entiende como una formalidad solemne, de modo que el que falta a la verdad jurada, no es sancionado por perjuro, sino que la "tipicidad" irroga de la declaración falsa y sus efectos. Bien es cierto que el perjurio se subsume e irroga de la falsedad jurada.

En el ámbito hispánico, la prueba testifical es el elemento nuclear del proceso, de modo que el testimonio es la fuente de la evidencia. En cambio, en los territorios ingleses del Bajo Medievo, los testigos de parte y los cojuradores desaparecen del contexto judicial, su testimonio tendría carácter preprocesal y su potencial falsedad quedaría exenta de responsabilidad. Los miembros del jurado son ahora los pesquisidores y los encargados de obtener las pruebas interrogando, sin ningún tipo de solemnidad o juramento, a los testigos directos de los hechos en sus lugares de residencia o trabajo. En consecuencia, no existe en todo el período bajomedieval inglés prueba testifical, de modo que el perjurio se restringe a los miembros del jurado, en tanto en cuanto hubiesen dictado un veredicto falso. Las previsiones del Common Law eran suficientes para atajar el improbable delito cometido de forma unánime por 12 personas libres, que de producirse, se integraba en el grupo de delitos no resarcibles, entre los que se hallaba el homicidio alevoso, sancionados con la pena talional corporal o capital a la que había o habría sido condenada la víctima como consecuencia del veredicto falso.

Quedan notas distintivas de la "tipicidad" que no hemos podido descubrir en la época objeto de estudio. Creemos que no existen, ni en las fuentes normativas hispánicas ni en las inglesas, títulos de punición de la falsedad inocua, de modo que el juez podría haber actuado a su arbitrio -cuando no existía dolo directo- eximiendo o atenuando la responsabilidad de los testigos cuando declaraban una verdad inverosímil o quimérica en todo distinta a la realidad material sin intención de causar perjuicio ajeno; cuando la declaración falsa no afectaba a cuestiones esenciales y transcendentales del proceso; o cuando el testigo declaraba falsamente por miedo insuperable.

\section{Bibliografía}

Agudo Romeo, Ma del Mar, "La Carta de Foro Bono de Cetina", Aragón en la Edad Media. Estudios de Economía y Sociedad, 14-15/1 (1999), pp. 35-48.

Albareda y Herrera, Manuel, El Fuero de Alfambra, Madrid: Imprenta de la Revista de Archivos, Bibliotecas y Museos, 1925.

Alejandre García, Juan Antonio, "El delito de falsedad testimonial en el Derecho histórico español”, Historia, Instituciones y Documentos, 3 (1976), pp. 9-140.

Alvarado Planas, Javier, El problema del germanismo en el Derecho español. Siglos $V$-XI, Madrid: Marcial Pons, 1997.

Archi, Gian Gualberto, Problemi in tema di falso nel diritto romano, Pavía: Studi nelle Scienze Giuridiche e Sociali ( $\left.n^{\circ} 26\right), 1941$. 
Arias Bonet, Juan Antonio, "Prueba testifical y 'obvagulatio' en el antiguo Derecho romano", en Francisci, Pietro de (ed.), Studi in onore di Pietro de Francisci, Milán: Giuffré, 1954, 2 vols, pp. 283-301.

Asso y del Río, Ignacio Jordan de y Manuel y Rodríguez, Miguel de, Fuero Viejo de Castilla, Madrid: Imprenta Joaquín Ibarra, 1771.

Attemborough, Frederick L., The Laws of the Earliest English Kings, Cambridge: Cambridge University Press, 1922.

Austin, Greta, Shaping Church Law around the Year 1000: The Decretum of Burchard of Worms, Farnham-Burlington: Ashgate, 2009.

Baker, John H., Introduction to English Legal History, Oxford: Oxford University Press, (4 ed), 2002.

Blackstone, William, Commentaries on the Laws of England, Chicago \& London: The University of Chicago Press, 1979.

Brunner, Heinrich ( $8^{\mathrm{a}}$ ed. von Schwerin, Claudius), Historia del Derecho germánico, trad. de Álvarez López, José Luis, Barcelona: Labor, 1936.

Coke, Edward, Institutes of the Lawes of England. The Third Part of the Institutes of the Laws of England; Concerning High Treason, and Other Pleas of the Crown and Criminal Causes, London, 1669.

Colección de Cortes de los Reynos de León y Castilla, Real Academia de la Historia, 1836.

Collectio Canonum Ecclesiae Hispaniae ex probatissimis ac pervetustis codicibus, Madrid: Typographia Regia, 1808.

Collins, Roger, "Visigothic law and regional custom in disputes in early medieval Spain," en Davies, Wendy y Fouracre, Paul (eds.), The Settlement of Disputes in Early Medieval Europe, Cambridge: Cambridge University Press, 1986, pp. 85104.

- "Law and Ethnic Identity in the Western Kingdoms in the Fifth and Sixth Centuries," en Medieval Europeans: Studies in Ethnic Identity and National Perspectives in Medieval Europe, New York: 1998, pp. 1-28.

Costa, Emilio, Crimine e pene da Romolo a Giustiniano, Bolonia: N. Zanichelli, 1921.

Councils \& Synods with Other Documents Relating to the English Church, eds. Brett, Martin, Powicke, Frederick Maurice, Cheney, Christopher Robert, Whitelock, Dorothy, Nugent, Christopher y Brooke, Lawrence, Oxford: Clarendon Press, 1981.

Crabb, George, A History of English Law or an Attempt to Trace the Rise, Progress, and Successive Changes of the Common Law; from the earliest Period to the Present Time, Burlington: Chauncey Goodrich, 1831.

D’Abadal i Vinyals, Ramón y Valls Taberner, Ferrán, Textes de dret català. Usatges de Barcelona. Barcelona, 1913.

De Groot, Roger, "The Jury of Presentment before 1215", The American Journal of Legal History, 26/1 (1982), pp. 1-24.

Del Giudice, Pascual., "Diritto penale germanico rispetto all'Italia", en Pessina Enrico (Dir.), Enciclopedia del Diritto penal italiano, vol. I, Milán: Società editrice libraria, 1905, pp. 429-609.

Díaz Canseco, Laureano, "Sobre los fueros del valle de Fenar, Castrocalbón y Pajares: notas para el estudio del Fuero de León", Anuario de Historia del Derecho Español, 1 (1924), pp. 337-381. 
Diccionario geográfico-histórico de España, Madrid: Real Academia de la Historia, 1802.

D’Ors, Álvaro, "La territorialidad del Derecho de los visigodos", Estudios Visigóticos, 1 (1956), pp. 91-150.

Dualde Serrano, Manuel, Fori Antiqui Valentiae, Escuela de Estudios Medievales, Madrid: C.S.I.C, 1967.

El Fuero Real de España, glosado por Alonso Díaz de Montalvo, Madrid, 1781.

Fernández de Buján Fernández, Antonio, "Testigos y documentos en la práctica negocial y judicial romana", Revista Jurídica de la Universidad Autónoma de Madrid, 12 (2005), pp. 117-142.

Fernández Duro, Cesáreo, "El Fuero de Sanabria", Boletín de la Real Academia de la Historia, 13 (1888).

Fernández Espinar, El falso testimonio judicial en el Derecho español, Granada: Majfer, 2005.

Ferro i Pomà, Victor, "Les constitucions i altres drets de Catalunya", en Documents Jurídics de la Història de Catalunya, Barcelona: Generalitat de Catalunya. Departament de Justicia, 1992, pp. 183-202.

Ferro i Pomà, Victor, El Dret Públic Catalá. Les institucions a Catalunya fins al Decret de Nova Planta, Vic: Eumo, 1987.

Ficker, Julius, Über die 'Usatici Barchinonae' und derem Zusammenhang mit den Exceptiones Legum Romanorum, Innsbruck: Ergänzungsband, 1888.

Figuerola, Laureano y Egusquiza, Antonio, Fueros, Privilegios, Franquezas, y Libertades Del M.N. y M.L. Señorio De Vizcaya, Confirmados Por El Rey Carlos III, Bilbao, 1761.

Flahiff, George B., "The Writ of Prohibition to Court Christian en the 13th Century", Mediaeval Studies 6 (1944), pp. 261-313.

Frantzen, Allen (ed.), The Anglo-Saxon Penitentials: A Cultural Database (ed. digital: www.anglo-saxon.net/penance/).

Fuero Juzgo en latín y castellano: cotejado con los más antiguos y preciosos códices, Madrid: Real Academia Española, 2002.

Galindez Suárez, Jesús, La legislación penal de Vizcaya, Bilbao, 1934.

García González, Juán, "El juramento de manquadra", Anuario de Historia del Derecho Español, 65 (1995), pp. 211-256.

García-Gallo, Alfonso, "Nacionalidad y territorialidad del Derecho en la época visigoda", Anuario de Historia del Derecho Español, 13 (1936-1941), pp. 168-264.

Gibert Sánchez de la Vega, Rafael, "El Derecho medieval de la Novenera", Anuario de Historia del Derecho Español, 21-22 (1951-1952), pp. 1216-1217.

Girard, Paul F. y Senn, Félix, Textes de droit romain, $7^{\mathrm{a}}$ ed., Paris, 1967.

González Alonso, Benjamín, "La fórmula 'obedézcase pero no se cumpla' en el Derecho castellano de la Baja Edad Media", en Anuario de Historia del Derecho Español, 50 (1980), pp. 469-488.

González González, Julio, Alfonso IX, II. Colección diplomática, Madrid, 1944.

González Ramos, José Ignacio, "El Fuero de Villafranca del Bierzo", Territorio, Sociedad y Poder. Revista de Estudios Medievales, 5 (2010), pp. 69-80.

González Rivas, Severino. La penitencia en la primitiva iglesia española. Estudio histórico, dogmático y canónico de la penitencia en la iglesia española desde sus orígenes hasta los primeros tiempos de la invasión musulmana, Salamanca: Consejo Superior de Investigaciones Científicas. Instituto Raimundo Peñafort, 1950. 
Gordon, Michael D., "The Perjury Statute of 1563: A case history of confusion", Proceedings of the American Philosophical Society, 124/ 6 (1980), pp. 438-454.

Granell Muñiz, Vicente, Ensayos histórico-jurídicos (Cojuradores; rebeldia; tradición; año y día en el fuero de Jaca), Oviedo, 1935.

Guy, John, Keen, Ralph, Miller, Clarence H. y Mcgugan, Ruth, The Complete Works of St. Thomas More, New Haven: Yale University, 1987.

Harries, Jill, Law and Empire in Late Antiquity, Cambridge: Cambridge University Press, 1999.

Harries, Jill. y Wood, Ian, (eds.), The Theodosian Code. Studies in the Imperial Law of Late Antiquity, London, 1993.

Hawarde, John, Les Reportes Del Cases in Camera Stellata, 1593 to 1609, London, 1894.

Hera Pérez-Cuesta de la, Alberto, "Falsus testis' y 'Delator'”, Anuario de Historia del Derecho Español, 33 (1963), pp. 365-390.

Hergueta, Narciso, "Fueros inéditos de Viguera y de Val de Funes otorgados por D. Alfonso el Batallador", Boletin de la Real Academia de la Historia, 37 (1900).

Hogan, John C, "Murder by perjury", Fordham Law Review, 30/2 (1961), pp. 285 296.

Holdsworth, William S., A History of English Law, London: Oxford University Press, 1927. 13 vols.

Hudson, William, "Court of Star Chamber: Hudson's 'Treatise of the Court", Collectanea Juridica vol I., ed. Hargrave, Francis, 1791-1792.

Hughes, James A., Witnesses in Criminal Trials of Clerics: An Historical Synopsis and Commentary, Washington, D. C.: The Catholic University of America (Canon Law Studies), 1937.

Iglesia Ferreirós, Aquilino, "Derecho municipal, derecho señorial, derecho regio", Historia, Instituciones, Documentos, 4 (1977), pp. 115-198.

Jean de la Coste, In Decretales Gregorii IX. Summaria, et Commentarii, Besoigne, 1676.

Jones, Michael E., "The Legacy of Roman Law in Post-Roman Britain," en Mathisen, Ralph. W. (ed.), Law, Society and Authority in Late Antiquity, Oxford: Oxford University Press, 2001, pp. 52-67.

King, Peter D. Law and Society in the Visigothic Kingdom, Cambridge: Cambridge University Press, 1972.

King, Peter D., "The alleged Territoriality of Visigothic Law", en Tierney, Brian y Linehan, Peter (Coords.), Authority and Power: Studies on Medieval Law and Government Presented to Walter Ullmann on His Seventieth Birthday, Cambridge: Cambridge University Press, 1980, pp. 1-11.

Klerman, Daniel, "Was the Jury ever Self-Informing?", South Californian Law Review, 77 (2003), pp. 123-149.

Labbé, Philippe y Cossart, Gabriel, Sacrosancta concilia ad regiam editionem exact: quae nunc quarta parte prodiit auctior, París, 1671.

Lacarra de Miguel, José María, "El Fuero de Estella", Anuario de Historia del Derecho Español, 4 (1927), pp. 404-450.

Lear, Floyd Seyward, "The Public Law of the Visigothic Code", Speculum, 26 (1951), pp. 1-23.

Llorente, Juan Antonio, Noticias historicas de las tres provincias Vascongadas, Madrid: Imprenta Real, 1808. 
López-Amo, Ángel, "La polémica en torno a la territorialidad del Derecho visigodo", Arbor 2 (1944), pp. 227-241.

Luard, Henry R., Annales Monastici, London: Rolls Series, 36 (1864).

MacNair, Mike, "The origins of the Jury: Vicinage and the Antecedents of the Jury", Law and History Review 17 (1999), pp. 537-599.

Mansferrer Domingo, Aniceto, La pena de infamia en el Derecho histórico español, Madrid: Dikynson, 2001.

Marquilles, Jacobi, Commentaria super Usaticis Barchinone, Barchinonis, J. Luschmer, 1505.

Martín Duque, Ángel J., "Fuero General de Navarra. Redacción Arcaica", Anuario de Historia del Derecho Español, 56 (1986), pp. 781-861.

Martín Mínguez, Bernardino, Las fórmulas tenidas por visigodas, Madrid, 1920.

Matthews, John F., Laying Down the Law, New Haven: Yale University Press, 2000.

Mayer, Ernst, Geschworenengericht und Inquisitionsprozess, Leipzig, 1916.

Merchant, Ronald A., The Church under Law: Justice Administration and Discipline in the Diocese of York, 1560-1640, Cambridge: Cambridge University Press, 1969.

Merea, Manuel Paulo, "Da miña gaveta”, Boletim da Faculdade do Direito, Universidade de Coimbra, 32 (1956), pp. 160-194.

Minguijón Adrián, Salvador, Historia del Derecho español, Cuaderno 9 (1927).

Mommsen, Theodor y Krueger, Paul, Corpus Iuris Civilis. Novellae Recognovit, Berlin, 1954.

Mommsen, Theodor, Römisches Strafrecht, Berlin Darmstadt: Akademie-Verlag, 1955.

Moriarty, Eugene J., "Oaths in Ecclesiastical Courts: An Historical Synopsis and Commentary", Canon Law Studies, 110 (1937), pp. 12-22.

Munier, Charles (ed.), Concilia Galliae, 314-506, Corpus Christianorum Series Latina, 148, Brepols, Turnhout: 1963.

Muñoz y Romero, Tomás, Colección de Fueros Municipales y cartas Puebla, Madrid: Imprenta de D. José María Alonso, 1817.

Murga Giner, José Luis, Derecho romano clásico, II: El proceso, Zaragoza: Universidad de Zaragoza, 1980.

Orlandis Rovira, José, "Las consecuencias del delito en el Derecho de la Alta Edad Media", Anuario de Historia del Derecho, 18 (1947), pp. 61-166.

Ortego Gil, Pedro, "Notas históricas sobre conato y tentativa", Initium, 19 (2014), pp. 421-523.

Otero Varela, Alfonso, "El riepto de los fueros municipales", Anuario de Historia del Derecho Español, 29 (1959), pp. 153-174.

Oton Sobrino, Enrique, "Notas críticas al texto de las Fórmulas visigóticas", Emérita, 38/1 (1970), pp. 125-130.

Peake, Thomas, Compendium of the Law of Evidence, London: W.T. Clarke, 1922.

Pérez-Prendes Muñoz-Arraco, José Manuel, "La Piedra Ensimismada. Notas sobre la investigación visigotista de Alfonso García-Gallo", Cuadernos de Historia del Derecho, 18 (2011), pp. 51-91.

Pérez de Urbel, Justo y Vázquez de Parga, Luis, "Un nuevo penitencial español", Anuario de Historia del Derecho Español, 14 (1942-1943), pp. 5-32.

Petit, Carlos, Iustitia Gothica. Historia social y teología del proceso en la Lex Visigothorum, Universidad de Huelva, Huelva: 2001. 
Pollock, Frederick y Maitland, Frederick W., The History of English Law, (2 ${ }^{\mathrm{a}}$ ed. 1898, reimpr. 1968), Cambridge: Cambridge University Press, 2 vols.

Prieto Moreira, Agustín, "El proceso en el Reino de León a la luz de los diplomas", en El reino de León en la Alta Edad Media. II. Ordenamiento jurídico del Reino de León, Colección "Fuentes y Estudios de Historia Leonesa", 49 (1992), pp. 383-518.

Ramos Loscertales, José María, "Textos para el estudio del Derecho aragonés en la Edad Media. (Compilación privada de Derecho aragonés; Constituciones de las Cortes de Huesca de 1188; Fuero de Calatayud)", Anuario de Historia del Derecho Español, 2 (1925), pp. 397-416.

Rhon, Gothard, Commentatio ad Edictum Theodorici, Regis Ostrogothorum, Halle an der Saale, 1816.

Riaza Martínez-Osorio, Román y García-Gallo, Alfonso, Manual de Historia del Derecho Español, Madrid: Gral. de Victoriano Suárez, 1934.

Roca Traver, Francisco, El Justicia de Valencia, 1239-1321, Valencia, 1970.

Romano, Clemente, De Constitutionibus Apostolicis, Venecia, 1563.

Sáez, Emilio, "Ordenamiento sobre Administración de Justicia dado por Pedro I a Sevilla en 1360", Anuario de Historia del Derecho Español, 17 (1946), pp. 712 750.

Salvador Esteban, Emilia, "Tortura y penas corporales en la Valencia foral moderna. El reinado de Fernando el Católico", Estudis: Revista de historia moderna, 22 (1996), pp. 263-289.

Sánchez Albornoz, Claudio, "Pervivencia y crisis de la tradición jurídica romana en la España goda", en Viejos y nuevos estudios sobre las instituciones medievales españolas, (3 vols.), vol. II, Madrid, 1976 (1959), pp. 1009-1077.

Sánchez, Galo, Fueros castellanos de Soria y Alcalá de Henares, Madrid, 1919.

- Libro de los Fueros de Castilla, Barcelona: Facultad de Derecho de Barcelona, 1924.

Sanxo y Vicens, Pere A., Antichs privilegis y franqueses del regne. Regnat de Jaume III, Palma, 1911.

Schultze, Alfred, Mit einem Exkurs "Zur Geschichte der westgotischen Rechtsquellen", Über westgotisch-spanisches Eherecht, Leipzig: S. Hirzel, 1944.

Schwerin, Claudio, "Sobre las relaciones entre las Fórmulas visigóticas y las andecavenses", Anuario de Historia del Derecho Español, 9 (1932), pp. 177-189.

Scio de San Miguel, Felipe, La Biblia Vulgata Latina, Madrid, 1816.

Stenton, Frank. M., Latin Charters of the Anglo-Saxon Period, Oxford: Oxford University Press, 1955.

Stephen, James F., The History of Criminal Law of England, Cambridge: Cambridge University Press, 1883.

Stubbs, William (ed.) Select Charters (2. ${ }^{\text {a }}$ ed.), Oxford: Oxford University Press, 1874.

Suárez, Francisco, De iuramento fidelitatis. Estudio preliminar, ed. de Pereña Vicente, Luciano, Abril Castelló, Vidal, Baciero González, Carlos, Garcia, Antonio, Belda, Francisco y Maseda, Francisco, Madrid: CSIC, 1979.

Tejada y Ramiro, Juan, Colección de cánones y de todos los concilios de la iglesia de España y de América, Madrid: Imprenta de Don Pedro Montero, 1859-1863. 2 vols. 
Thorpe, Benjamin, Ancient and Institutes of England, London, 1840.

Tilander, Gunnar, Fueros de Aragón, según el manuscrito 458 de la Biblioteca Nacional de Madrid, Lund: Leges Hispanicae Medii Aevii, 1937.

Tomás y Valiente, Francisco, El Derecho penal de la Monarquía absoluta (siglos XVI, XVII y XVIII), Madrid: Tecnos, 1969.

Tucker, Charles E., "Anglo-Saxon Law: Its Development and Impact on the English Legal System", en USAFA Journal of Legal Studies, 2 (1991), pp. 127-202.

Ureña y Smenjaud, El Fuero de Zorita de los Canes, Madrid: Real Academia de la Historia, 1911.

Ureña y Smenjaud, Rafael de, La Legislación Gótico Hispana, Madrid: Idamor Moreno, 1905.

- Fuero de Cuenca, Madrid: Academia de la Historia, 1935.

Uriarte Lebario, Luis Ma de, El Fuero de Ayala, Palma: Consejo Insular, 1912.

Wallace-Hadrill, John Michael, Early Germanic Kingship in England and on the Continent, Oxford: Oxford University Press, 1971.

Whitman, James Q., The Origins of Reasonable Doubt: Theological Roots of the Criminal Trial, New Haven: Yale University Press, 2008.

Whittaker, William J., Mirror of Justices, London: Selden Society, 1895.

Wilkins, David, Concilia magnae britanniae, London, 1737.

Woodcock, Brian L., Medieval Ecclesiastical Courts in the Diocese of Canterbury, Oxford: Oxford University Press, 1952.

Yanguas y Miranda, José, Diccionario de Antigüedades del Reino de Navarra, vol. III, Pamplona: Imprenta de José Imaz y Gadea, 1840.

Zeumer, Karl, Historia de la legislación española, trad. de Clavería, Carlos, Barcelona: Universidad de Barcelona, 1944. 